This document was prepared in conjunction with work accomplished under Contract No. DE-AC09-96SR18500 with the U. S. Department of Energy.

\title{
DISCLAIMER
}

This report was prepared as an account of work sponsored by an agency of the United States Government. Neither the United States Government nor any agency thereof, nor any of their employees, nor any of their contractors, subcontractors or their employees, makes any warranty, express or implied, or assumes any legal liability or responsibility for the accuracy, completeness, or any third party's use or the results of such use of any information, apparatus, product, or process disclosed, or represents that its use would not infringe privately owned rights. Reference herein to any specific commercial product, process, or service by trade name, trademark, manufacturer, or otherwise, does not necessarily constitute or imply its endorsement, recommendation, or favoring by the United States Government or any agency thereof or its contractors or subcontractors. The views and opinions of authors expressed herein do not necessarily state or reflect those of the United States Government or any agency thereof. 


\section{AN ORDER-OF-MAGNITUDE ESTIMATION OF BENZENE CONCENTRATION IN SALTSTONE VAULT}

A. S. Choi

March 2006

Immobilization Technology Section Savannah River National Laboratory Aiken, SC 29808

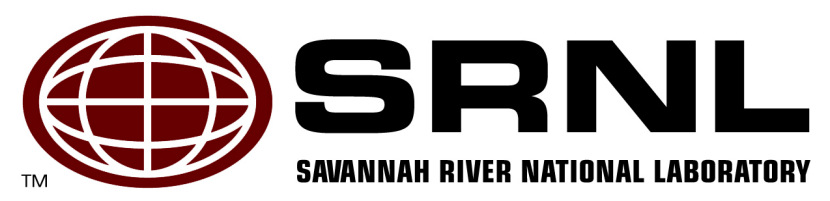




\section{DISCLAIMER}

This report was prepared by Westinghouse Savannah River Company (WSRC) for the United States Department of Energy under Contract No. DE-AC09-96SR18500 and is an account of work performed under that contract. Neither the United States Department of Energy, nor WSRC, nor any of their employees makes any warranty, expressed or implied, or assumes any legal liability or responsibility for the accuracy, completeness, or usefulness, of any information, apparatus, or product or process disclosed herein or represents that its use will not infringe privately owned rights. Reference herein to any specific commercial product, process, or service by trademark, name, manufacturer or otherwise does not necessarily constitute or imply endorsement, recommendation, or favoring of same by WSRC or by the United States Government or any agency thereof. The views and opinions of the authors expressed herein do not necessarily state or reflect those of the United States Government or any agency thereof.

\section{Printed in the United States of America \\ Prepared For U.S. Department of Energy}


Key Words: Tank 48, TPB,

Saltstone Vault,

Benzene

Retention: Permanent

\section{AN ORDER-OF-MAGNITUDE ESTIMATION OF BENZENE CONCENTRATION IN SALTSTONE VAULT}

A. S. Choi

March 2006

Immobilization Technology Section Savannah River National Laboratory Aiken, SC 29808

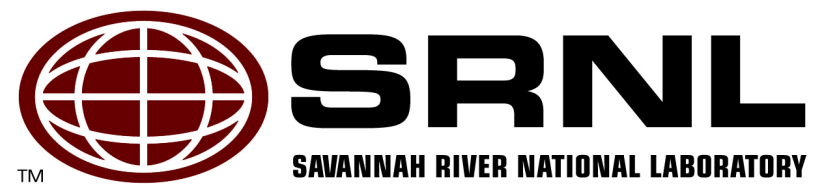




\section{REVIEWS AND APPROVALS}

\section{AUTHOR:}
28Curi
A. S. Choi, PSE/SRNL
$\frac{3-6-2006}{\text { Date }}$

\section{TECHNICAL REVIEWERS:}

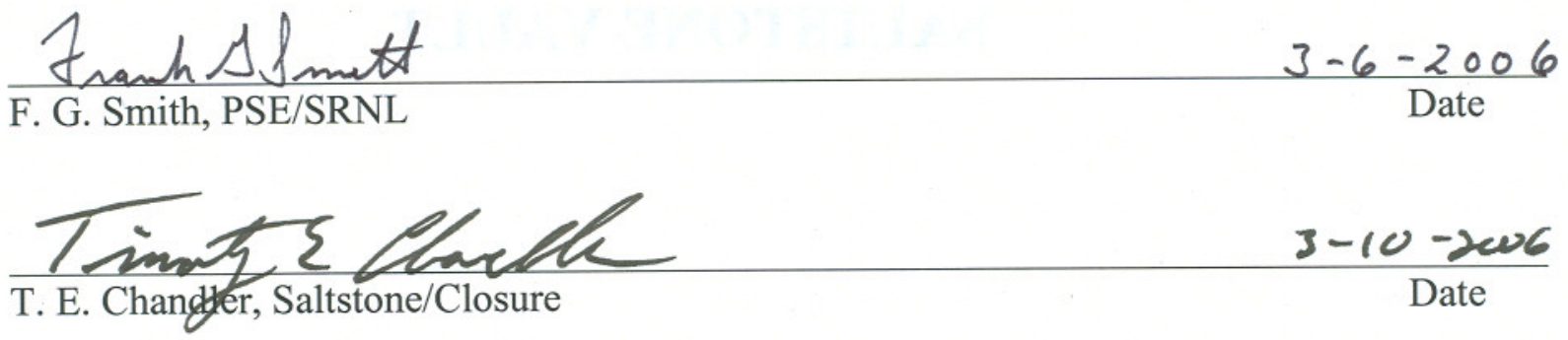

\section{APPROVERS}

\begin{tabular}{lc} 
REEd ds & $3 / 8 / 06$ \\
\hline R. E. Edwards, Manager, Process Science \& Engineering Section/SRNL & Date
\end{tabular}

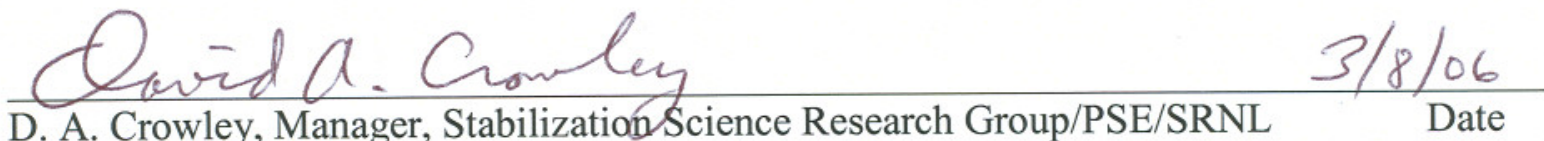

D. A. Crowley, Manager, Stabilization Science Research Group/PSE/SRNL Date

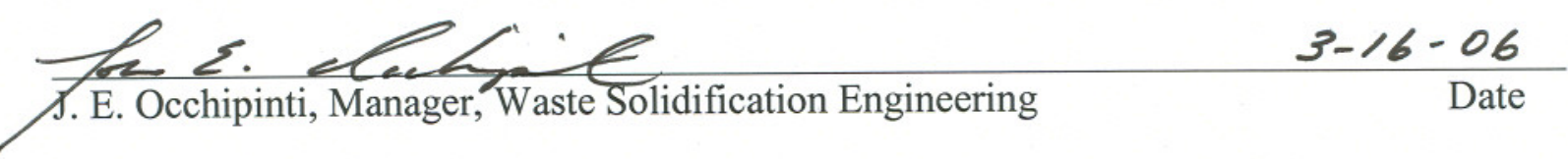




\section{EXECUTIVE SUMMARY}

The contents of Tank $48 \mathrm{H}$ that include the tetraphenylborate (TPB) precipitates of potassium and cesium will be grouted and stored in the Saltstone vault. The grouting process is exothermic, which should accelerate the rate of decomposition of TPB precipitates eventually to benzene. Because the vault is not currently outfitted with an active ventilation system, there is a concern that a mixture of flammable gases may form in the vapor space of each cell filled with the curing grout. The purpose of this study was to determine if passive breathing induced by the diurnal fluctuations of barometric pressure would provide any mitigating measure against potential flammability in the cell vapor space.

In Revision 0 of this document, a set of algorithms were presented that would predict the equilibrium concentration of benzene in the cell vapor space as a function of benzene generation rate, fill height, and passive breathing rate. The algorithms were derived based on several simplifying assumptions so that order of magnitude estimates could be made quickly for scoping purposes. In particular, it was assumed that passive breathing would occur solely due to barometric pressure fluctuations that were sinusoidal; the resulting algorithm for estimating the rate of passive breathing into or out of each cell is given in Eq. (10).

Since Revision 0 was issued, the validity of this critical assumption on the mode of passive breathing was checked against available passive ventilation data for the Hanford waste tanks. It was found that the passive breathing rates estimated from Eq. (10) were on average 50 to $90 \%$ lower than those measured for 5 out of 6 Hanford tanks considered in this study (see Table 1); for Tank U-106, the estimated passive breathing rates were on average $20 \%$ lower than the measured data. These results indicate that Eq. (10) would most likely under predict passive breathing rates of the Saltstone vault. At a given fill height and benzene generation rate, under predicted breathing rates would in turn make the benzene concentration projections in the cell vapor space conservatively high, thus rendering the overall flammability assessment conservative. The results of this validation effort are summarized in Section 2.4 of this revision. It is to be noted that all the algorithms, numerical results and conclusions made in Revision 0 remain valid.

In this work, the algorithms for estimating the equilibrium benzene concentration for a given scenario were derived by combining the asymptotic solutions to the transient mass balance equations for the exhaling and inhaling modes in a 24-hour period. These algorithms were then applied to simulate several test cases, including the baseline case where the cell was filled to the maximum height of $25 \mathrm{ft}$ at the bulk benzene generation rate of $3.4 \mathrm{~g} / \mathrm{hr}$.

Based on the results of the case studies, the following conclusions can be drawn:

- At $3.4 \mathrm{~g} / \mathrm{hr}$ benzene generation rate, passive breathing induced by the diurnal oscillations of atmospheric pressure is sufficient enough to limit the maximum benzene concentration below $50 \%$ of the LFL, thus mitigating potential flammability in the Saltstone vault vapor space without installing any active ventilation system.

- At $34 \mathrm{~g} / \mathrm{hr}$ benzene generation rate, it is estimated to take 23 and 5 days to reach $100 \%$ and $25 \%$ of the LFL, respectively, at $25 \mathrm{ft}$ fill height. At $17 \mathrm{ft}$ fill height, it is estimated to take 30 days to reach $25 \%$ of the LFL with the maximum equilibrium concentration of benzene at just below the LFL.

- At $34 \mathrm{~g} / \mathrm{hr}$ benzene generation rate, the advantage of atmospheric breathing over the nonbreathing case becomes only marginal at $25 \mathrm{ft}$ fill height. 
- At benzene generation rates higher than $340 \mathrm{~g} / \mathrm{hr}$, the atmospheric breathing no longer has any positive impact on the time to LFL at both 17 and $25 \mathrm{ft}$ fill levels.

The following algorithms are further recommended for a quick estimation of equilibrium benzene mole fractions $y_{B Z N}$ in the Saltstone vault vapor space at given benzene generation rate $m_{B Z N}$ in $g / h r$ in the absence of any active ventilation device:

- At $25 \mathrm{ft}$ fill height:

- At $17 \mathrm{ft}$ fill height:

$$
\begin{aligned}
& \frac{1}{y_{B Z N}}=0.37627+\frac{586.581}{\dot{m_{B Z N}}} \\
& \frac{1}{y_{B Z N}}=0.46973+\frac{2,915.163}{\dot{m_{B Z N}}}
\end{aligned}
$$




\section{TABLE OF CONTENTS}

EXECUTIVE SUMMARY iii

LIST OF FIGURES vi

LIST OF TABLES vi

LIST OF ACRONYMS

1.0 INTRODUCTION AND BACKGROUND

vii

2.0 analysis

2.1 Assumptions

2.2 Atmospheric Breathing through Porous Media

2.3 Application to Saltstone Vault

2.4 Validation of Atmospheric Breathing Predictions 8

2.5 Derivation of Breathing Algorithms 11

2.5.1 Exhaling_1 11

2.5.2 Exhaling_2 12

2.5.3 Inhaling 13

3.0 case studies $\quad 15$

3.1 No Atmospheric Breathing 16

3.2 Atmospheric Breathing with Baseline Benzene Rate 18

3.3 Atmospheric Breathing at 10X Baseline Benzene Generation 21

3.4 Atmospheric Breathing at 100X Baseline Benzene Generation 23

3.5 Atmospheric Breathing at 1000X Baseline Benzene Generation 25

4.0 CONCLUSIONS $\quad 29$

5.0 RECOMMENDATIONS/PATH FORWARD 31

6.0 REFERENCES 


\section{LIST OF FIGURES}

Figure 1. Schematic of Saltstone Vault Cell and Barometric Pressure Oscillation................. 3

Figure 2. Barometric Pressure Induced Subsurface Transport Studied by Auer et al. ${ }^{2}$........... 5

Figure 3. Profiles of Measured vs. Calculated Passive Breathing Rates of Tank U-103. .... 10

Figure 4. Barometric Pressures at Hanford Site During Tank U-103 Ventilation Test......... 10

Figure 5. Schematic of Inlet and Outlet Flows during Exhaling_1.................................. 11

Figure 6. Schematic of Inlet and Outlet Flows during Exhaling_2 ................................. 12

Figure 7. Schematic of Inlet and Outlet Flows during Inhaling................................... 13

Figure 8. Benzene Concentration Profile in Cell Vapor Space at $25 \mathrm{ft}$ Fill Height. ............. 19

Figure 9. Benzene Concentration Profile in Cell Vapor Space at $17 \mathrm{ft} \mathrm{Fill} \mathrm{Height..............} 19$

Figure 10. Benzene Concentration Profile at $34 \mathrm{~g} / \mathrm{hr}$ Benzene Rate \& $25 \mathrm{ft}$ Fill Height. ...... 22

Figure 11. Benzene Concentration Profile at $34 \mathrm{~g} / \mathrm{hr}$ Benzene Rate \& $17 \mathrm{ft}$ Fill Height. ...... 22

Figure 12. Benzene Concentration Profile at $340 \mathrm{~g} / \mathrm{hr}$ Benzene Rate \& $25 \mathrm{ft}$ Fill Height. .... 24

Figure 13. Benzene Concentration Profile at $340 \mathrm{~g} / \mathrm{hr}$ Benzene Rate \& $17 \mathrm{ft}$ Fill Height. .... 24

Figure 14. Benzene Concentration Profile at 3,400 g/hr Benzene Rate \& $25 \mathrm{ft}$ Fill Height. . 26

Figure 15. Benzene Concentration Profile at 3,400 g/hr Benzene Rate \& $17 \mathrm{ft}$ Fill Height. . 26

Figure 16. Components of Benzene Concentration Profile at 3,400 g/hr Benzene Rate....... 27

Figure 17. Equilibrium Benzene Concentration Profile at 25 Ft Fill Height...................... 30

Figure 18. Equilibrium Benzene Concentration Profile at 17 Ft Fill Height....................... 30

\section{LIST OF TABLES}

Table 1. Comparison of Measured vs. Calculated Passive Breathing Rates of Selected

Hanford Waste Tanks..................................................................................... 9

Table 2. Volumetric Flow Fraction of Benzene and First-Order Time Constant.................. 15

Table 3. Saltstone Vault Operating Data Used in Baseline Case...................................... 15

Table 4. Values of Solution Parameters at $3.4 \mathrm{~g} / \mathrm{hr}$ Benzene Generation Rate..................... 18

Table 5. Impact of Atmospheric Breathing at 3.4 g/hr Benzene Generation Rate............... 20

Table 6. Values of Solution Parameters at $34 \mathrm{~g} / \mathrm{hr}$ Benzene Generation Rate..................... 21

Table 7. Impact of Atmospheric Breathing at $34 \mathrm{~g} / \mathrm{hr}$ Benzene Generation Rate................ 21

Table 8. Values of Solution Parameters at $340 \mathrm{~g} / \mathrm{hr}$ Benzene Generation Rate................... 23

Table 9. Impact of Atmospheric Breathing at $340 \mathrm{~g} / \mathrm{hr}$ Benzene Generation Rate.............. 23

Table 10. Values of Solution Parameters at 3,400 g/hr Benzene Generation Rate............... 25

Table 11. Impact of Atmospheric Breathing at 3,400 g/hr Benzene Generation Rate.......... 25 


\section{LIST OF ACRONYMS}

$\begin{array}{ll}\text { AB } & \text { atmospheric breathing } \\ \text { EXH } & \text { exhaling } \\ \text { HMS } & \text { Hanford Meteorological Station } \\ \text { INH } & \text { inhaling } \\ \text { LFL } & \text { lower flammability limit } \\ \text { NAB } & \text { no atmospheric breathing } \\ \text { TPB } & \text { tetraphenylborate } \\ \text { TTR } & \text { Task Technical Request }\end{array}$


WSRC-TR-2005-00071

Revision 1

This page intentionally left blank. 


\subsection{INTRODUCTION AND BACKGROUND}

The contents of Tank $48 \mathrm{H}$ that include the tetraphenylborate (TPB) precipitates of potassium and cesium will be grouted and stored in the Saltstone vault. The grouting process is exothermic, which should accelerate the decomposition of TPB precipitates eventually to benzene. Since the vault is not outfitted with an active ventilation system, there is a concern that a mixture of flammable gases may form in the vapor space of each cell filled with the curing grout. The purpose of this study was to determine if the passive breathing induced by the diurnal fluctuations of barometric pressures would provide any mitigating measure against potential flammability.

Specifically, it was requested that a set of algorithms be developed that would predict the equilibrium concentration of benzene as a function of benzene generation rate, fill height, and the amplitude of barometric pressure fluctuations. These algorithms were to be derived based on several simplifying assumptions so that order of magnitude estimates could be made quickly for scoping purposes. This report documents the methodology used to derive such algorithms along with several key assumptions made. These algorithms were then applied to simulate several test cases, including the baseline case where the cell was filled to the maximum height of $25 \mathrm{ft}$ and the rate of benzene generation was fixed at $3.4 \mathrm{~g} / \mathrm{hr}$. 
WSRC-TR-2005-00071

Revision 1

This page intentionally left blank. 


\subsection{ANALYSIS}

Figure 1 shows a schematic of one of the six cells in the Saltstone Vault \#4 that are to be filled with the Tank 48 grout. Each $100 \mathrm{ft}$ by $100 \mathrm{ft}$ cell is $26 \mathrm{ft}$ high at the outer wall $\left(H_{o}\right)$ and $28 \mathrm{ft}$ high $\left(H_{i}\right)$ at the inner wall, and the walls are 18-inch thick. When the wall thickness is taken into consideration, the internal cell dimensions become $98.5 \mathrm{ft}$ by $98.5 \mathrm{ft}$ for a total cell volume of $261,961 \mathrm{ft}^{3}{ }^{1}$. The roof is 4 to 6 inch thick and has two diagonally-opposed 12-inch diameter vents, and the total vent opening is equivalent to less than $0.02 \%$ of the surface area of the roof.

Also shown is the assumed sinusoidal variation of the barometric pressure due to diurnal temperature variations. The amplitude of the sinusoidal pressure oscillations is set at 2.5 mbar about the mean pressure of 1,103 mbar. ${ }^{1}$ When the atmospheric pressure begins to fall in the evening, the system will exhale, i.e., the vapor in the cell will discharge, while the system will inhale when the atmospheric pressure begins to rise in the morning. The amplitude of atmospheric pressure oscillations is generally higher with the passage of weather fronts. However, they were not considered in this study, since they occur over a longer time-scale so that the average rate of pressure oscillations may become comparable to or even smaller than the diurnal rate.

The main focus of this work is to develop an algorithm for the equilibrium concentration of benzene in the remaining vapor space of each cell after it is filled with grout to a height $h$. The benzene that could potentially accumulate in the void spaces within the grout matrix is not the area of concern for this work.
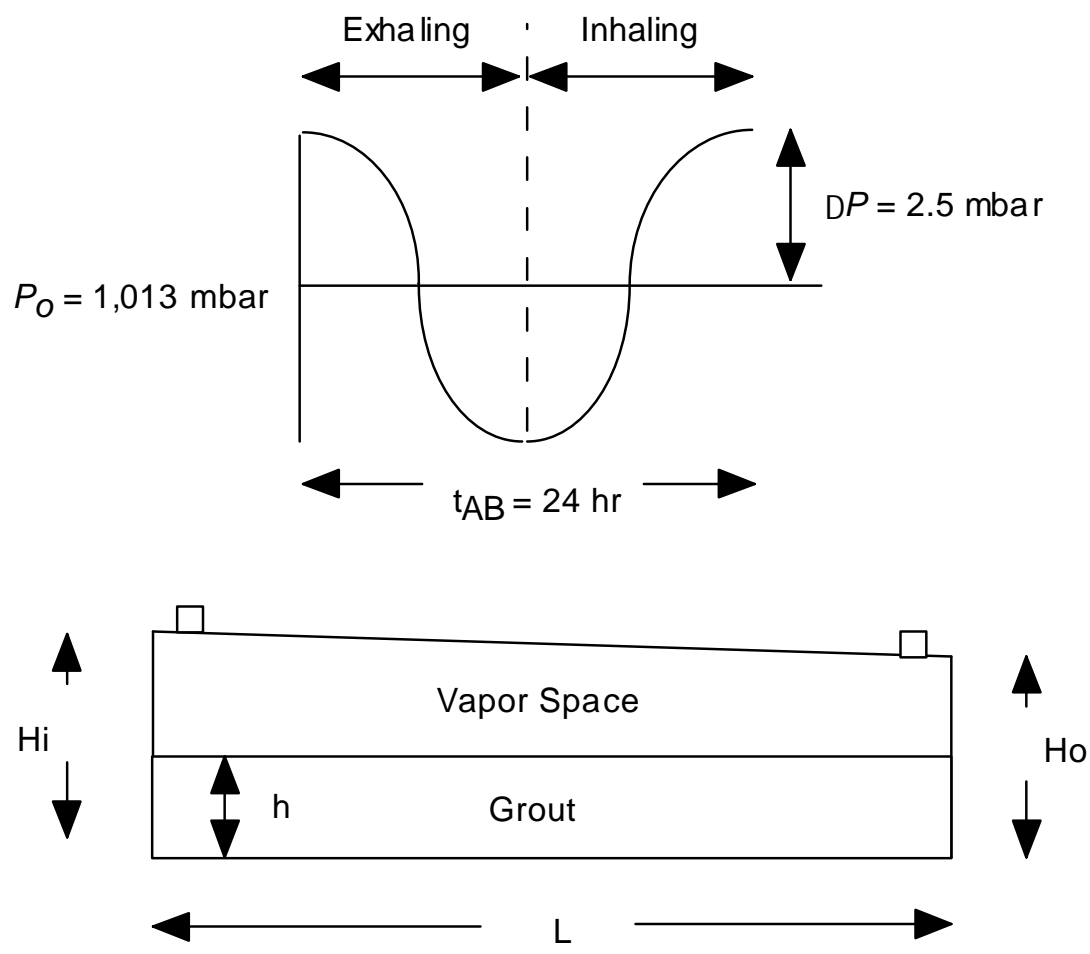

Figure 1. Schematic of Saltstone Vault Cell and Barometric Pressure Oscillation. 


\subsection{Assumptions}

1. The rate of benzene generation is constant, i.e., time-invariant, at all fill levels.

2. Benzene is the only gas evolving from the grout matrix.

3. The initial concentration of benzene in the vapor space is zero.

4. The grout matrix covers the entire cross-sectional area of the cell and forms an impermeable boundary with no cracks. This allows the vapor space volume to be calculated as the total cell volume minus the volume of grout matrix.

5. The vapor space is perfectly mixed so the pressure, temperature and concentration are uniform throughout.

6. The diurnal atmospheric pressure oscillations are sinusoidal with the amplitude of 2.5 mbar.

7. Atmospheric breathing occurs uniformly in time during each of the exhaling and inhaling periods.

\subsection{Atmospheric Breathing through Porous Media}

Atmospheric breathing is induced by the pressure gradient imposed between the Saltstone vault and the surrounding atmosphere and its rate can be estimated from the results of the analysis by Auer et $\mathrm{al}^{2}$ They studied the transport of subsurface contaminants induced by the atmospheric pressure perturbation that varies harmonically as $P_{z=0}-P_{o}=\Delta P e^{i \omega t},{ }^{3}$ as shown in Figure 2, and derived the following approximation for the pore-scale air velocity at depth $z$ :

$$
v \cong-\frac{\Delta P}{P_{o}}(L-z)\left(\frac{2 \pi}{t_{A B}}\right) \sin \left(\frac{2 \pi}{t_{A B}} t\right)
$$

Equation 1

where $L$ is the total depth to the impermeable lower boundary, $\Delta P$ the amplitude of the sinusoidal barometric pressure oscillations, $P_{o}$ the mean atmospheric pressure, and $t_{A B}$ the period of atmospheric breathing $(\mathrm{AB})$. The resulting subsurface pressure will be attenuated to some degree depending on the permeability of the porous medium and further show some time delay. Eq. (1) is valid when the pressure attenuation is relatively small, and it clearly shows that under those conditions the actual air velocity through the porous medium or "barometric pumping" depends on the relative pressure perturbation $\left(\Delta P / P_{o}\right)$ and its period and the depth of the porous medium but not on the physical properties of the porous medium. The Darcy velocity is then calculated as the pore-scale velocity times the porosity $(\phi)$.

The vertical displacement of air or soil vapor resulting from the barometric pumping can be obtained by integrating Eq. (1) from $t=0$ to $t=t$ as follows:

$$
\begin{aligned}
\Delta z & =z(t)-z(0) \\
& \cong \frac{\Delta P}{P_{o}}(L-z) \cos \left(\frac{2 \pi}{t_{A B}} t\right)-\frac{\Delta P}{P_{o}}(L-z) \cos \left(\frac{2 \pi}{t_{A B}}(0)\right) \\
& \cong-\frac{\Delta P}{P_{o}}(L-z)\left[1-\cos \left(\frac{2 \pi}{t_{A B}} t\right)\right]
\end{aligned}
$$

Equation 2 


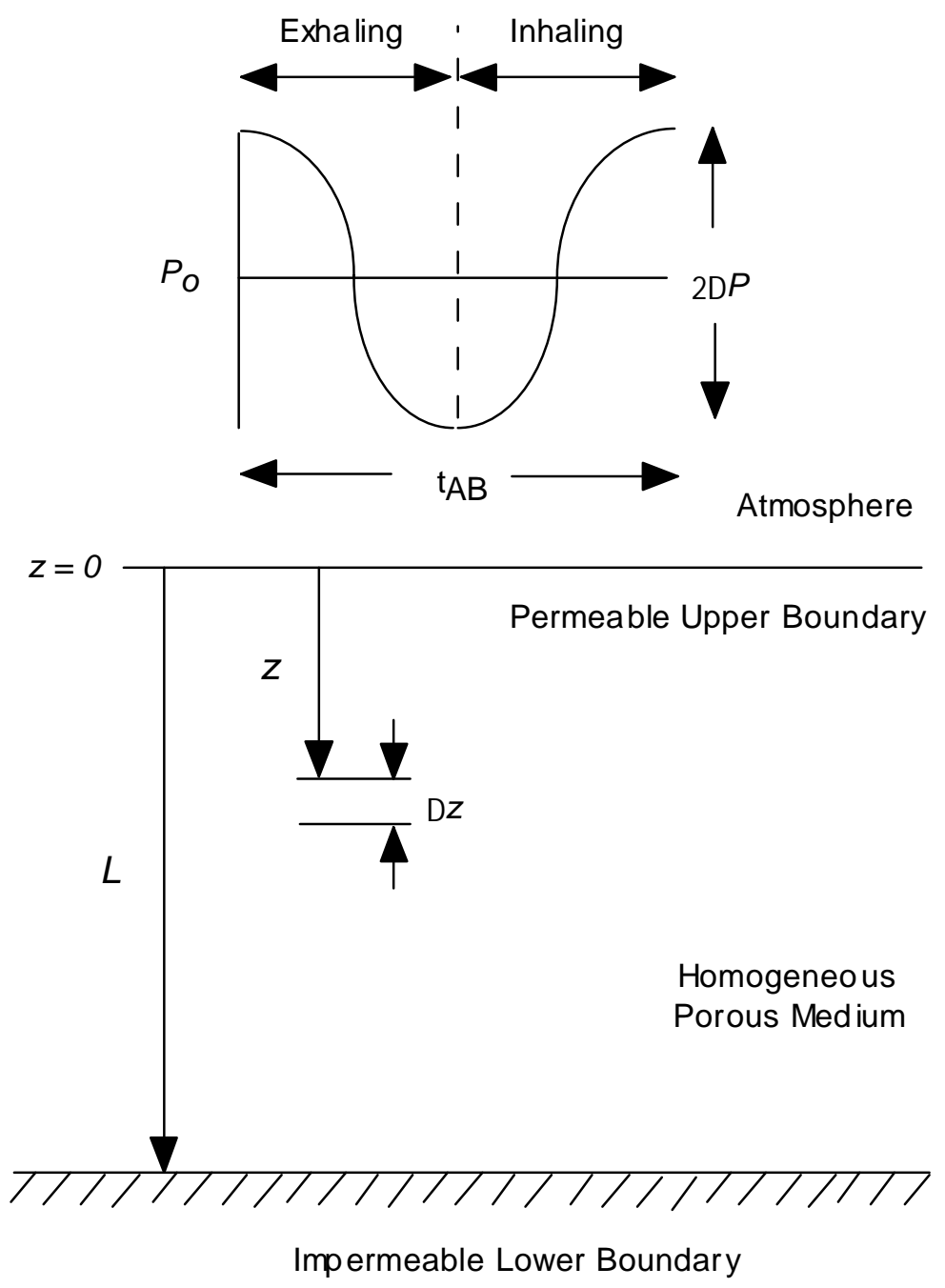

Figure 2. Barometric Pressure Induced Subsurface Transport Studied by Auer et al. ${ }^{2}$

As expected, Eq. (2) shows that at a given time $t$ the displacement is the largest just beneath the surface at $z=O$ and decreases linearly to zero as the depth is increased to $L$. Furthermore, the maximum displacement of $-2\left(\Delta P / P_{o}\right)(L-z)$ will occur at $t=t_{A B} / 2$, where the negative sign indicates that the displacement is in the upward direction toward the surface. Therefore, the deepest layer of air evacuated during a period of barometric pumping can be calculated by equating the maximum displacement to its corresponding position:

$$
z_{m b p}=2\left(\frac{\Delta P}{P_{o}}\right)\left(L-z_{m b p}\right)
$$

Equation 3

where the subscript $m b p$ stands for the maximum barometric pumping. If the amplitude of the barometric shift is defined as $L_{p u m p}=\left(\Delta P / P_{o}\right) L$, as was done in Reference 2, and substitute it into Eq. (3), we obtain the following: 


$$
z_{m b p}=\frac{2 L_{p u m p}}{1+2 \frac{L_{p u m p}}{L}}
$$

Equation 4

Furthermore, we obtain the following equality from the definition of $L_{\text {pump }}$ :

$$
\frac{L_{\text {pump }}}{L}=\frac{\Delta P}{P_{o}}
$$

Equation 5

Since $\Delta P / P_{o} \cdot 0.005$ for typical diurnal barometric oscillations, $L_{p u m p} / L \cdot O$ and Eq. (4) is reduced to:

$$
\begin{aligned}
z_{m b p} & =2 L_{p u m p} \\
& =2\left(\frac{\Delta P}{P_{o}}\right) L
\end{aligned}
$$

Equation 6

Finally, the average velocity of displacement during an exhaling mode between $t=0$ and $t=t_{A B} / 2 \mathrm{can}$ be calculated by dividing the total displacement by the duration:

$$
\begin{aligned}
\bar{v}_{E X H} & =\frac{-2\left(\frac{\Delta P}{P_{o}}\right) L}{\frac{t_{A B}}{2}} \\
& =-4\left(\frac{\Delta P}{P_{o}}\right)\left(\frac{L}{t_{A B}}\right)
\end{aligned}
$$

Equation 7

where the subscript ${ }_{E X H}$ denotes "exhaling," and the negative sign was inserted because the displacement is in the negative $z$ direction toward the surface during an exhaling mode. Likewise, the average velocity of displacement during an inhaling mode between $t=t_{A B} / 2$ and $t=t_{A B}$ can be shown as:

$$
\bar{v}_{I N H}=4\left(\frac{\Delta P}{P_{o}}\right)\left(\frac{L}{t_{A B}}\right)
$$

Equation 8

where the subscript ${ }_{I N H}$ denotes "inhaling." It should be noted here that identical expressions for the atmospheric breathing velocities can also be obtained by integrating Eq. (1) directly. For example, the average exhaling velocity can be calculated by integrating from $t=0$ to $t=t_{A B} / 2$ : 


$$
\begin{aligned}
\bar{v}_{E X H} & =\frac{\int_{0}^{t_{A B}}-\frac{\Delta P}{P_{o}}(L-z)\left(\frac{2 \pi}{t_{A B}}\right) \sin \left(\frac{2 \pi}{t_{A B}} t\right) d t}{\frac{t_{A B}}{2}} \\
& =\frac{\left[\frac{\Delta P}{P_{o}}(L-z) \cos \left(\frac{2 \pi}{t_{A B}} t\right)\right]_{0}^{\frac{t_{A B}}{2}}}{\frac{t_{A B}}{2}} \\
& =-4\left(\frac{\Delta P}{P_{o}}\right)\left(\frac{L-z_{m b p}}{t_{A B}}\right)
\end{aligned}
$$

\section{Equation 9}

Substituting Eq. (6) for $z_{m b p}$, we obtain:

$$
\begin{aligned}
\bar{v}_{E X H} & =-4\left(\frac{\Delta P}{P_{o}}\right)\left(\frac{L}{t_{A B}}\right)\left(1-2 \frac{\Delta P}{P_{o}}\right) \\
& \cong-4\left(\frac{\Delta P}{P_{o}}\right)\left(\frac{L}{t_{A B}}\right)
\end{aligned}
$$

which is identical to Eq. (7) derived earlier. Likewise, the average inhaling velocity given in Eq. (8) can be obtained by integrating Eq. (1) from $t=t_{A B} / 2$ to $t=t_{A B}$. Note that in this approach the signs of respective breathing velocities are automatically taken care of.

\subsection{Application to Saltstone Vault}

As stated earlier, it can be concluded from the work by Auer et al. that when the attenuation is relatively insignificant, the barometric pumping depends only on the relative pressure perturbation $\left(\Delta P / P_{o}\right)$ and its period and the depth or size of the porous medium but not on its physical properties such as permeability. ${ }^{2}$ Therefore, the fact that the pressure attenuation in the Saltstone vault vapor space will be negligible should work in favor of further substantiating the applicability of the preceding analysis to the atmospheric breathing in the Saltstone vault.

The additional similarities between the two systems shown in Figure 1 and Figure 2 that justify the application include:

- Both systems are subject to the sinusoidal pressure perturbations.

- Both systems have an impermeable lower boundary.

- Both systems have homogeneous media.

- Vapor transport in both systems can be approximated as one-dimensional.

However, before we apply Eqs. (7) and (8) to the Saltstone vault, the linear breathing velocities, $\bar{v}_{E X H}$ and $\bar{v}_{I N H}$, are replaced with the volumetric flow rate $Q$ by substituting the cell vapor space volume $V$ for the depth $L$ as: 
WSRC-TR-2005-00071

Revision 1

$$
Q_{A B}=4\left(\frac{\Delta P}{P_{o}}\right)\left(\frac{V}{t_{A B}}\right)
$$

Equation 10

Eq. (10) represents the average volumetric rates of both exhaling and inhaling modes, and the only difference between the two is in the sign or direction, as shown in Eqs. (7) and (8). The substitution was made possible, since the cell vapor space has a constant cross-sectional area of $98.5 \mathrm{ft}$ by $98.5 \mathrm{ft}$.

\subsection{Validation of Atmospheric Breathing Predictions}

The validity of Eq. (10) was checked against the measured passive ventilation rates of the selected Hanford waste tanks using either helium $(\mathrm{He})$ or sulfur hexafluoride $\left(\mathrm{SF}_{6}\right)$ as the tracer gas. ${ }^{4,5}$ Once a sufficient quantity of tracer gas was injected into a tank headspace, a series of measurements were made over a period of one month to nearly a year spanning from 1997 to 1998 . The headspace volumes were calculated by subtracting measured waste volume from that of the empty tank. ${ }^{6,7}$ The amplitudes of diurnal barometric pressure fluctuations at the Hanford Site were calculated from the hourly barometric pressure readings taken by the Hanford Meteorological Station (HMS). ${ }^{8,9}$

The calculated breathing rates of the selected Hanford tanks are compared in Table 1 to the measured passive ventilation rates. It is clearly seen that Eq. (10) under predicts the data on average by 50 to $90 \%$ for 5 out of 6 Hanford tanks considered in this study; for Tank U-106, the calculated breathing rates were on average $20 \%$ lower than the measured data. Of particular interest is the extensive set of ventilation rate data collected from Tank U-103 over a period of 11 months from February 1997 to January 1998. Figure 3 shows the seasonal impact on the passive ventilation rates of Tank U-103; the measured breathing rates from 18-Nov-97 to 8-Jan-98 were on average about $65 \%$ higher than those measured from 28-May-97 to 1-Oct-97. The calculated breathing rates of Tank U-103 are also shown to track the measured data fairly well and exhibit the same seasonal trend. It is easy to see from Figure 4 why the calculated breathing rates are much higher in the winter than in the summer; the amplitudes of barometric pressure variations at the Hanford Site were much greater in the winter than in the summer and, according to Eq. (10), the passive breathing rate is directly proportional to $\Delta P$.

It is also noted in Figure 3 that the profiles of both measured and calculated breathing rates roughly coincide. So, just by comparing the scales of both y-axes, it may then be concluded that the measured breathing rates of Tank U-103 were on average 4 times higher than those calculated from Eq. (10). This is equivalent to saying that the calculated passive breathing rates of Tank U-103 accounted for roughly $25 \%$ of the measured data, which compares well with the average breathing rate difference of $-73 \%$ given in Table 1 for the entire 11-month period. This large under prediction is mainly due to the fact that Eq. (10) accounts for the passive breathing induced only by the barometric pressure variations, whereas the measured data inevitably include other effects as well that may potentially have a much greater impact.

One such effect is the so-called "chimney effect" resulting from the thermal gradients that exist between the tank headspace and ambient air and within the tank headspace. The chimney effect is expected to be more pronounced in the winter, since cold ambient air will try to sink, while warmer headspace vapor will try to rise, thereby setting up a continuous circulation of air and headspace vapor, provided both an inlet and an outlet vents are present. This may explain why the measured Tank U-103 ventilation rates were much higher in the winter than in the summer. The impact of the chimney effect on passive breathing is expected to be particularly significant in the Saltstone vaults, since each cell is equipped with two 1-ft diameter vents located at the opposite corners of its square roof. These vents provides a pathway for continuous circulation of ambient air and headspace vapor 
WSRC-TR-2005-00071

Revision 1

Table 1. Comparison of Measured vs. Calculated Passive Breathing Rates of Selected Hanford Waste Tanks.

\begin{tabular}{|c|c|c|c|c|c|c|c|}
\hline \multirow{2}{*}{$\begin{array}{l}\text { Tank } \\
\text { ID }\end{array}$} & \multicolumn{2}{|c|}{ Test Dates } & \multicolumn{2}{|c|}{ Measured Data } & \multicolumn{2}{|c|}{ Calc'd using Eq. (10) } & \multirow{2}{*}{$\begin{array}{c}\begin{array}{c}\text { Average } \\
\text { Diff. }\end{array} \\
(\%)\end{array}$} \\
\hline & From & To & $\left(\mathrm{m}^{3} / \mathrm{hr}\right)$ & $\left(\mathrm{ft}^{3} / \min \right)$ & $\left(\mathrm{ft}^{3} / \min \right)$ & $\%$ of Data & \\
\hline \multirow{2}{*}{ TX-102 } & 14-Jan-98 & 22-Jan-98 & 6.00 & 3.53 & 1.95 & 55 & \multirow{2}{*}{-48} \\
\hline & 22-Jan-98 & 12-Feb-98 & 5.90 & 3.47 & 1.72 & 50 & \\
\hline \multirow{3}{*}{ U-102 } & 9-Jan-98 & 15-Jan-98 & 3.00 & 1.77 & 0.91 & 51 & \multirow{3}{*}{-60} \\
\hline & 15-Jan-98 & 13-Feb-98 & 4.80 & 2.83 & 0.96 & 34 & \\
\hline & 13-Feb-98 & 24-Mar-98 & 2.70 & 1.59 & 0.62 & 39 & \\
\hline \multirow{11}{*}{ U-103 } & 27-Feb-97 & 6-Mar-97 & 4.90 & 2.88 & 0.64 & 22 & \multirow{11}{*}{-73} \\
\hline & 6-Mar-97 & 31-Mar-97 & 4.00 & 2.35 & 0.70 & 30 & \\
\hline & 31-Mar-97 & 9-Apr-97 & 5.20 & 3.06 & 0.60 & 20 & \\
\hline & 9-Apr-97 & 28-May-97 & 2.60 & 1.53 & 0.52 & 34 & \\
\hline & 28-May-97 & 15-Jul-97 & 2.20 & 1.29 & 0.39 & 30 & \\
\hline & 15-Jul-97 & 22-Jul-97 & 3.50 & 2.06 & 0.48 & 23 & \\
\hline & 22-Jul-97 & 13-Aug-97 & 2.40 & 1.41 & 0.37 & 26 & \\
\hline & 13-Aug-97 & 1-Oct-97 & 2.20 & 1.29 & 0.52 & 40 & \\
\hline & 1-Oct-97 & 18-Nov-97 & 3.40 & 2.00 & 0.50 & 25 & \\
\hline & 18-Nov-97 & 15-Dec-97 & 4.30 & 2.53 & 0.63 & 25 & \\
\hline & 15-Dec-97 & 8-Jan-98 & 3.60 & 2.12 & 0.65 & 31 & \\
\hline \multirow{2}{*}{ U-105 } & 18-Jul-97 & 24-Jul-97 & 7.40 & 4.36 & 0.50 & 12 & \multirow{2}{*}{-90} \\
\hline & 24-Jul-97 & 15-Aug-97 & 8.80 & 5.18 & 0.46 & 9 & \\
\hline \multirow{3}{*}{ U-106 } & 9-Jan-98 & 15-Jan-98 & 2.50 & 1.47 & 1.18 & 80 & \multirow{3}{*}{-19} \\
\hline & 15-Jan-98 & 13-Feb-98 & 2.20 & 1.29 & 1.25 & 96 & \\
\hline & 13-Feb-98 & 24-Mar-98 & 2.10 & 1.24 & 0.81 & 66 & \\
\hline \multirow{3}{*}{ U-111 } & 9-Jan-98 & 15-Jan-98 & 4.80 & 2.83 & 1.09 & 39 & \multirow{3}{*}{-54} \\
\hline & 15-Jan-98 & 13-Feb-98 & 3.50 & 2.06 & 1.15 & 56 & \\
\hline & 13-Feb-98 & 24-Mar-98 & 2.70 & 1.59 & 0.75 & 47 & \\
\hline
\end{tabular}

* Average Difference $(\%)=($ calculated value - measured data $) /$ measured data $* 100$

and the 2 -ft elevation difference that exists between them will provide an equivalent hydrostatic pressure differential of $7 \mathrm{~Pa}$, which would further enhance convection in the headspace, as confirmed by a recent computational fluid dynamics (CFD) study. ${ }^{10}$

Another effect not included in Eq. (10) is the wind effect. When wind blows across the top of a tank, it will cause a vacuum at the vent openings due to the Bernoulli effect, resulting in the vapor being drawn out of the tank. These non barometric pressure effects all tend to enhance passive breathing, which explains why the calculated breathing rates of Tank U-103 using Eq. (10) accounted for only about $25 \%$ of the measured rates nearly throughout the year. As a comparison, a recent study estimated that the barometric pressure variations accounted for about $10 \%$ and $15 \%$ of the measured Tank U-103 ventilation rates in the winter and the summer, respectively, ${ }^{11}$ which are even lower than what Eq. (10) predicted. The same study also estimated that the chimney effect accounted for about $50 \%$ and $15 \%$ of the measured ventilation rates in the winter and summer, respectively, while the remaining $40 \%$ and $70 \%$ were attributed to the wind effect in the winter and summer, respectively. Thus, it is more than likely that Eq. (10) would lead to under prediction of passive breathing rates by a wide margin, which would make the equilibrium benzene concentration estimates in the cell vapor space conservatively high. 


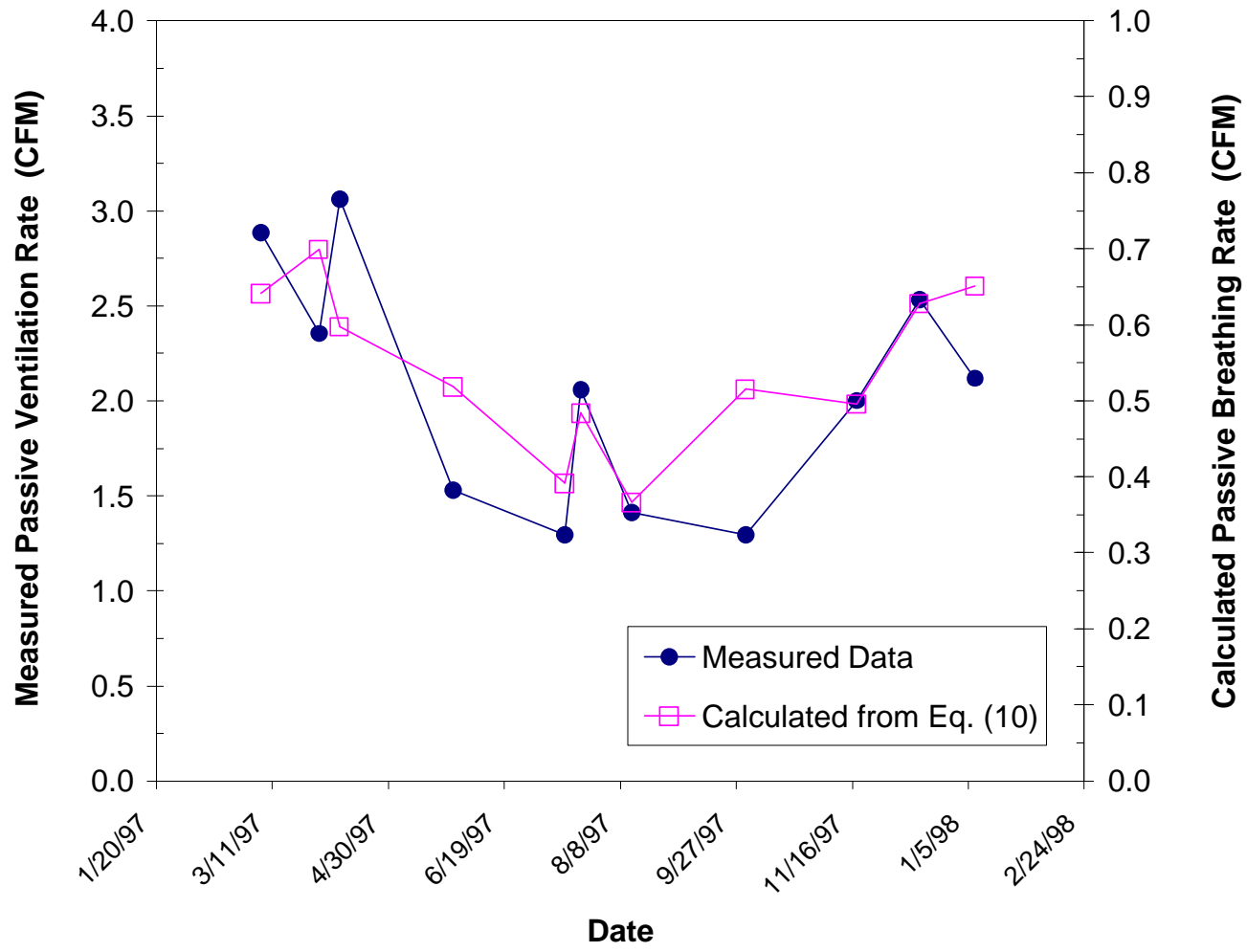

Figure 3. Profiles of Measured vs. Calculated Passive Breathing Rates of Tank U-103.

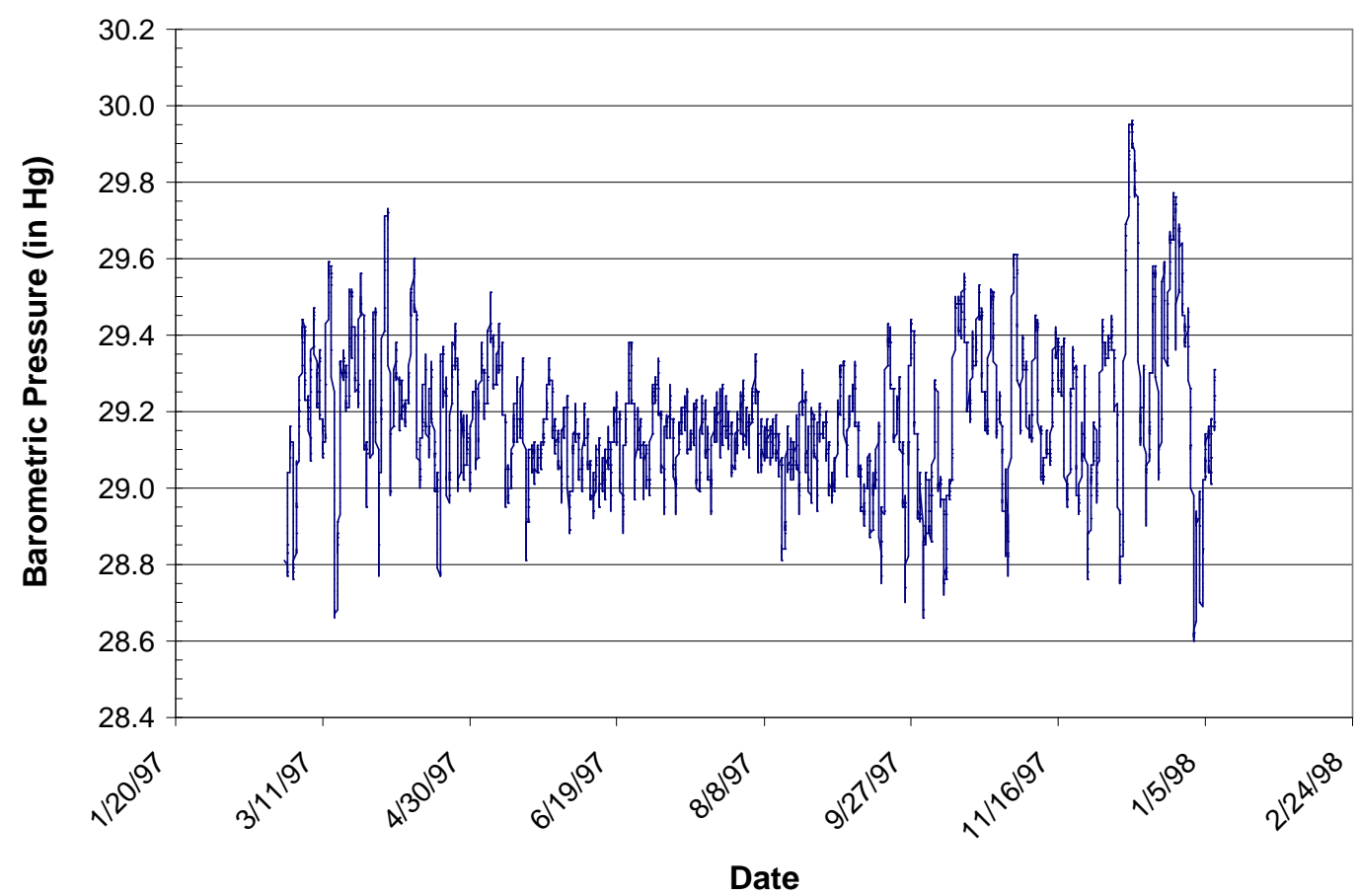

Figure 4. Barometric Pressures at Hanford Site During Tank U-103 Ventilation Test. 


\subsection{Derivation of Breathing Algorithms}

Since the direction of atmospheric breathing reverses twice during a 24-hour period, the mass balance must be performed separately for the exhaling and inhaling modes.

\subsubsection{Exhaling_1}

Figure 5 shows a schematic of gas flows in and out of the cell vapor space during an exhaling mode as the ambient temperature begins to fall in the evening hours.

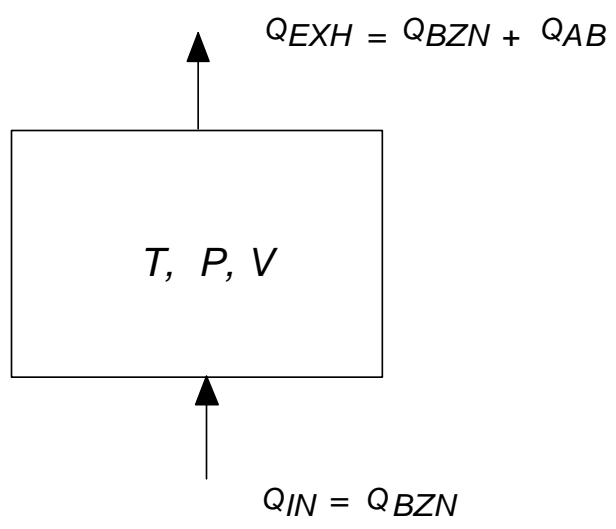

Figure 5. Schematic of Inlet and Outlet Flows during Exhaling_1.

The relevant benzene mole balance equation is:

$$
V \frac{d C_{B Z N}}{d t}=Q_{B Z N}\left(\frac{P}{R T}\right) y_{B Z N, I N}-Q_{E X H}\left(\frac{P}{R T}\right) y_{B Z N}
$$

Equation 11

where $C_{B Z N}$ is the molar concentration of benzene in mole/ $\mathrm{ft}^{3}, Q_{B Z N}$ the benzene generation rate in $\mathrm{ft}^{3} / \mathrm{hr}, Q_{E X H}$ the exhaling rate in $\mathrm{ft}^{3} / \mathrm{hr}$, and $y$ the mole fraction. Note that $y_{B Z N, I N}=1$ from Assumption \#2. Further applying the ideal gas law, $C_{B Z N}=y_{B Z N} P / R T$, and substituting the net exhaling flow rate, $Q_{E X H}=Q_{B Z N}+Q_{A B}$,Eq. (4) can be re-written as:

$$
\frac{d y_{B Z N}}{d t}+\frac{Q_{B Z N}+Q_{A B}}{V} y_{B Z N}=\frac{Q_{B Z N}}{V}
$$

Equation 12

It is noted in Figure 5 that when $P=0, Q_{A B}=0$ and $Q_{E X H}=Q_{B Z N}$, as it should to maintain a constant pressure in the cell. Eq. (1) is a first-order linear differential equation and has the following solution:

$$
y_{B Z N}(t)=\left(y_{B Z N}(o)-Q F R C_{B Z N_{-} E X H 1}\right) \exp \left(-\frac{t}{\tau_{E X H 1}}\right)+Q F R C_{B Z N_{-} E X H 1} \quad \text { Equation } 13
$$


where $y_{B Z N}(o)$ is the initial mole fraction of benzene in the cell vapor space, $Q F R C_{B Z N_{-} E X H I}$ is the volume fraction of benzene in the outlet flow during the exhaling_1 mode defined as:

$$
Q F R C_{B Z N_{-} E X H 1}=\frac{Q_{B Z N}}{Q_{B Z N}+Q_{A B}}
$$

Equation 14

and • is the first-order time constant for the exhaling_1 mode defined as:

$$
\tau_{E X H 1}=\frac{V}{Q_{B Z N}+Q_{A B}}
$$

It should be noted here that the time-dependent atmospheric breathing rate similar to Eq. (1) could have been substituted for $Q_{A B}$ in Eq. (12) instead of the average rate given by Eq. (10). However, although this would have made the resulting solution mathematically more rigorous, it would not necessarily reflect the reality any better, since the actual atmospheric pressure variations are not truly sinusoidal.

\subsubsection{Exhaling_2}

When $Q_{B Z N}>Q_{A B}$, the system could still be exhaling, even though the ambient pressure is rising during the daytime, and the pressure gradient is imposed so as to induce inhaling. This is because the net inhaling flow, $Q_{I N H}=Q_{A B}-Q_{B Z N}$ is negative. Therefore, as shown in Figure 6, the rate of the net exhaling flow is calculated as $Q_{E X H}=Q_{B Z N}-Q_{A B}$.

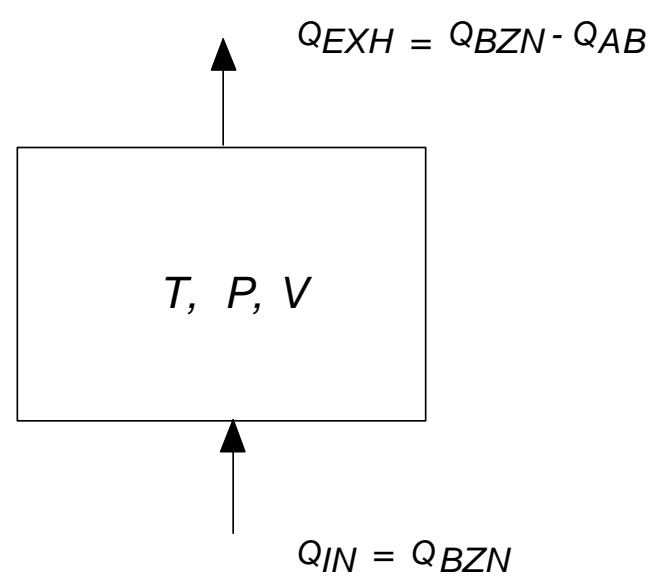

Figure 6. Schematic of Inlet and Outlet Flows during Exhaling_2.

Note that when $\bullet P=0, Q_{A B}=0$ and $Q_{E X H}$ is again equal to $Q_{B Z N}$, as it should in order to maintain a constant cell pressure. Since the flow directions are identical to those shown in Figure 5, the benzene mole balance equation is also identical to Eq. (11), and the relevant differential equation is:

$$
\frac{d y_{B Z N}}{d t}+\frac{Q_{B Z N}-Q_{A B}}{V} y_{B Z N}=\frac{Q_{B Z N}}{V}
$$


The solution to Eq. (16) is identical to Eq. (13) except that $Q F R C_{B Z N}$ during the exhaling_2 mode is now defined as:

$$
Q F R C_{B Z N_{-} E X H 2}=\frac{Q_{B Z N}}{Q_{B Z N}-Q_{A B}}
$$

Equation 17

and $\bullet$ is defined as:

$$
\tau_{E X H 2}=\frac{V}{Q_{B Z N}-Q_{A B}}
$$

\subsubsection{Inhaling}

When $Q_{B Z N}<Q_{A B}$, the system will inhale as the ambient pressure rises during the daytime. As shown in Figure 7, the rate of the net inhaling flow is calculated as $Q_{I N H}=Q_{A B}-Q_{B Z N}$, and note that there are no outlet flows during this period. Furthermore, since $Q_{B Z N}$ is assumed to be positive in this study, $Q_{A B}$ cannot be zero or $\bullet P \bullet O$.

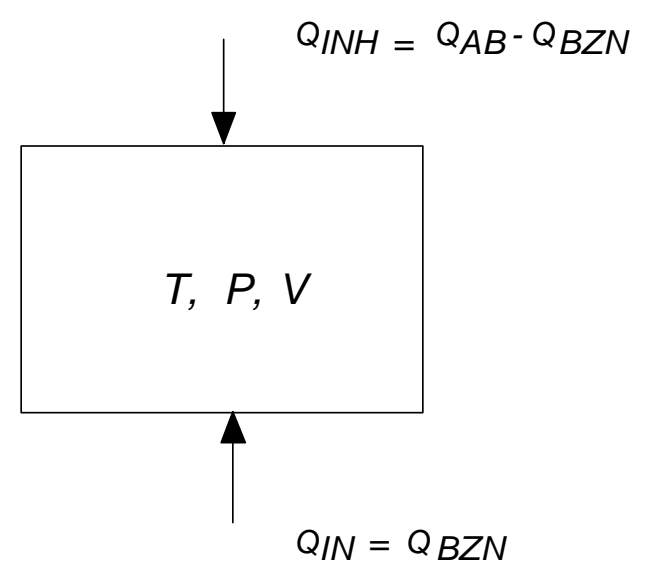

Figure 7. Schematic of Inlet and Outlet Flows during Inhaling.

The relevant benzene mole balance equation becomes:

$$
V \frac{d C_{B Z N}}{d t}=Q_{B Z N}\left(\frac{P}{R T}\right) y_{B Z N, I N}+Q_{I N H}\left(\frac{P_{o}}{R T_{o}}\right) y_{B Z N, o}
$$

Equation 19

where $Q_{I N H}$ is the inhaling rate in $\mathrm{ft}^{3} / \mathrm{hr}$, and $y_{B Z N, o}$ the mole fraction of benzene in ambient air, which is zero.

The resulting mole balance equation is then:

$$
V \frac{d C_{B Z N}}{d t}=Q_{B Z N}\left(\frac{P}{R T}\right)
$$


It should be noted that the cell pressure was assumed to remain constant in the previous two exhaling modes, since the amplitude of diurnal barometric pressure variations is small, i.e., less than $0.5 \%$. If the cell pressure is also assumed to remain constant during the inhaling mode, the solution to Eq. (20) is then simply:

$$
y_{B Z N}(t)=\frac{Q_{B Z N}}{V} t+y_{B Z N}(o)
$$

Equation 21

The implication of Eq. (21) is that the benzene concentration will increase linearly with time and the entire vapor space will be eventually filled with pure benzene. However, this scenario is not feasible because during the inhaling mode ambient air will infiltrate at a higher rate than that of the benzene generation, resulting in continuous dilution of the benzene concentration instead of concentrating it. To overcome this difficulty, the cell pressure was allowed to vary in this case, as there are no outlet flows unlike the exhaling modes. The relevant total mole balance equation is then:

$$
\frac{d n_{t}}{d t}=Q_{B Z N}\left(\frac{P}{R T}\right)+Q_{I N H}\left(\frac{P_{o}}{R T_{o}}\right)
$$

Equation 22

where the subscript o denotes the ambient conditions. Since the degree of the cell pressure variations will be still relatively insignificant compared to the ambient pressure, it is assumed that $P_{o} \bullet P$ and $T_{o}$ - $T$. Upon further substituting $Q_{I N H}=Q_{A B}-Q_{B Z N}$, Eq. (22) is reduced to:

$$
\frac{d n_{t}}{d t}=\frac{Q_{A B}}{V} n_{t}
$$

whose solution is simply:

$$
n_{t}(t)=n_{t}(o) \exp \left(\frac{Q_{A B}}{V} t\right)
$$

Equation 24

where $n_{t}(o)$ is the total number of moles in the vapor space at $t=0$. After substituting $C_{B Z N}=n_{t} y_{B Z N} / V$ in Eq. (20) followed by differentiation and further substitution of Eq. (24) for $n_{t}$, we have:

$$
\frac{d y_{B Z N}}{d t}+\frac{Q_{A B}}{V} y_{B Z N}=\frac{Q_{B Z N}}{V}
$$

Equation 25

whose solution is of the same form as Eq. (13) except that $Q F R C_{B Z N}$ for the inhaling mode is now defined as:

$$
Q F R C_{B Z N_{-} I N H}=\frac{Q_{B Z N}}{Q_{A B}}
$$

\section{Equation 26}


and $\bullet$ is defined as:

$$
\tau_{I N H}=\frac{V}{Q_{A B}}
$$

Equation 27

In summary, since the relevant differential mass balance equations are of the same form for both exhaling and inhaling modes, the general form of their solutions is also of the same form as Eq. (13); they only differ in the definitions of $Q F R C_{B Z N}$ and $\bullet$, as shown below:

Table 2. Volumetric Flow Fraction of Benzene and First-Order Time Constant.

\begin{tabular}{||c|c|c||}
\hline Breathing Mode & $Q F R C_{B Z N}$ & $\tau(h r)$ \\
\hline Exhaling_1 & $\frac{Q_{B Z N}}{Q_{B Z N}+Q_{A B}}$ & $\frac{V}{Q_{B Z N}+Q_{A B}}$ \\
\hline Exhaling_2 & $\frac{Q_{B Z N}}{Q_{B Z N}-Q_{A B}}$ & $\frac{V}{Q_{B Z N}-Q_{A B}}$ \\
\hline Inhaling & $\frac{Q_{B Z N}}{Q_{A B}}$ & $\frac{V}{Q_{A B}}$ \\
\hline
\end{tabular}

\subsection{CASE STUDIES}

It is important to note that each atmospheric breathing cycle can occur in pairs of either (Exhaling_l + Exhaling_2) or (Exhaling_1+ Inhaling), depending on the relative magnitudes of the atmospheric breathing rate $Q_{A B}$ and the benzene generation rate $Q_{B Z N}$. The breathing pair (Exhaling_2 + Inhaling) is not physically feasible, since it would mean that ambient air never cools down.

In this work, four different breathing modes, including no atmospheric breathing, were considered at two different fill heights for a total of eight cases in all. The values of $Q F R C_{B Z N}$ and $\tau$ defined in Table 2 need to be determined first to simulate the cyclical variations of atmospheric breathing for each case. Table 3 summarizes the operating data used for the baseline case, including the diurnal barometric pressure change of 5 mbar or \pm 2.5 mbar about the mean value of 1,013 mbar. $^{1}$ The goal was to estimate the equilibrium benzene concentrations in the cell vapor space using the algorithms derived in the preceding section. The cell dimensions used in the case studies were given earlier in this report.

Table 3. Saltstone Vault Operating Data Used in Baseline Case.

\begin{tabular}{||l|c||}
\hline \multicolumn{1}{|c|}{ Parameter } & Value \\
\hline Benzene generation rate, $\dot{m}_{B Z N}(\mathrm{~g} / \mathrm{hr})$ & 3.4 \\
\hline Maximum fill height, $H_{\max }(\mathrm{ft})$ & 25 \\
\hline Minimum fill height, $H_{\min }(\mathrm{ft})$ & 17 \\
\hline Maximum vapor space temperature, $T_{\max }\left({ }^{\circ} \mathrm{C}\right)$ & 95 \\
\hline Period of atmospheric breathing, $t_{A B}(\mathrm{hr})$ & 24 \\
\hline Amplitude of barometric pressure oscillation, $\Delta P$ (mbar) & 2.5 \\
\hline Mean barometric pressure, $P_{o}$ (mbar) & 1,013 \\
\hline
\end{tabular}




\subsection{No Atmospheric Breathing}

This case was run to quantify the relative impact of atmospheric breathing on the equilibrium benzene concentration and the time to LFL. In the absence of atmospheric breathing, the cell vapor must be discharged to the atmosphere at the same volumetric rate as that of benzene entering from the grout matrix. Therefore, the mode of gas flows is identical to that of Exhaling_1 shown in Figure 5, except that $Q_{E X H}=Q_{B Z N}$. The concentration of benzene is then given as:

$$
y_{B Z N}(t)=\left(y_{B Z N}(o)-1\right) \exp \left(-\frac{t}{\tau_{N A B}}\right)+1
$$

\section{Equation 28}

where $\tau_{N A B}=V / Q_{B Z N}$ and the subscript ${ }_{\mathrm{NAB}}$ denotes no atmospheric breathing. It is noted that Eq. (28) is obtained from Eq. (13) simply by letting $Q_{A B} \rightarrow 0$.

Since the LFL of benzene is at $y_{B Z N}=0.012$, the time to LFL is calculated as:

$$
t_{L F L, N A B}=-\frac{V}{Q_{B Z N}} \ln (1-0.012)
$$

Equation 29

The vapor space volume $V$ is calculated as:

$$
\begin{aligned}
V & =V_{\text {cell }}-V_{\text {grout }} \\
& =L_{\text {eff }}^{2}\left(H_{o}+\frac{\left(H_{i}-H_{o}\right)}{2}-H\right)
\end{aligned}
$$

where $L_{\text {eff }}$ is the effective cell length, which is given as $98.5 \mathrm{ft}$ after taking into account the vault wall thickness. ${ }^{1}$ After substituting the values for $H_{o}, H_{i}$, and $L_{\text {eff }}$ in Eq. (30), the volume of the cell vapor space in $f t^{3}$ is calculated as:

$$
V=9,702.25(27-H)
$$

Equation 31

At $H=H_{\max }=25 \mathrm{ft}$, the vapor space volume is calculated to be $19,404.5 \mathrm{ft}^{3}$.

The baseline volumetric rate of benzene generation is calculated from the mass generation rate as: 


$$
\begin{aligned}
Q_{B Z N} & =\frac{m_{B Z N}}{M W_{B Z N}}\left(\frac{R T}{P}\right) \\
& =\frac{3.4 \frac{g}{h r}}{78 \frac{g}{g m o l e}} \frac{1.013 \text { bar }}{\text { gmole } K}(273.15+95) K \\
& =0.046552 \frac{\mathrm{ft}^{3}}{\mathrm{hr}}
\end{aligned}
$$

Therefore, the time to LFL in the absence of atmospheric breathing is:

$$
\begin{aligned}
t_{L F L} & =-\frac{19,404.5}{0.046552} \ln (1-0.012) \\
& \approx 5,032 \mathrm{hr} \\
& \approx 210 \text { days }
\end{aligned}
$$

Likewise, the time to $25 \%$ of the LFL in the absence of atmospheric breathing is:

$$
\begin{aligned}
t_{25 \% \text { LFL }} & =-\frac{19,404.5}{0.046552} \ln (1-(0.012)(0.25)) \\
& \approx 1,252 \mathrm{hr} \\
& \approx 52 \text { days }
\end{aligned}
$$

At the fill height $H=H_{\min }=17 \mathrm{ft}$, the vapor space volume is calculated to be 97,022.5 $\mathrm{ft}^{3}$ from Eq. (31). By repeating the same calculations above, it can be shown that the corresponding times to $100 \%$ and $25 \%$ LFL at $17 \mathrm{ft}$ fill height are:

$$
\begin{aligned}
& t_{\text {LFL }}=1,048 \text { days } \\
& t_{25 \% \text { LFL }}=261 \text { days }
\end{aligned}
$$

These results show that it would take five times longer to reach the threshold LFL points at $17 \mathrm{ft}$ fill height than at $25 \mathrm{ft}$ fill height, since the vapor space volume of the former case is five times larger than that of the latter. It can also be shown from Eq. (28) that in the absence of atmospheric breathing the maximum concentration of benzene will eventually reach $y_{B Z N}=1$ or pure benzene at both fill heights. 


\subsection{Atmospheric Breathing with Baseline Benzene Rate}

The algorithm for estimating the atmospheric breathing rate in $f t^{3} / h r$ is obtained by substituting $t_{A B}=$ $24 h r$ and Eq. (31) for $V$ in Eq. (10):

$$
Q_{A B}=1,617.042(27-H) \frac{\Delta P}{P_{o}}
$$

Equation 32

At the given amplitude of barometric pressure oscillations of $\Delta P=2.5 \mathrm{mbar}$, the rate of atmospheric breathing $Q_{A B}$ is calculated to be $\sim 8.0$ and $39.9 \mathrm{ft}^{3} / \mathrm{hr}$ at 25 and 17 fill heights, respectively. Since $Q_{B Z N}$ $\ll Q_{A B}$, the relevant breathing pair for the baseline case is (Exhaling_l + Inhaling). The calculated values of $Q F R C_{B Z N}$ and $\tau$ are tabulated in Table 4:

Table 4. Values of Solution Parameters at $3.4 \mathrm{~g} / \mathrm{hr}$ Benzene Generation Rate.

\begin{tabular}{||c|c|c|c|c|c|c||}
\hline \hline \multirow{2}{*}{ Breathing Mode } & \multicolumn{2}{|c|}{$Q_{A B}\left(f t^{3} / h r\right)$} & \multicolumn{2}{c|}{$Q F R C_{B Z N}$} & \multicolumn{2}{c||}{$\tau(h r)$} \\
\cline { 2 - 7 } & $H=25 f t$ & $H=17 f t$ & $H=25 f t$ & $H=17 f t$ & $H=25 f t$ & $H=17 f t$ \\
\hline Exhaling_1 & 7.9814 & 39.9072 & 0.00580 & 0.00117 & 2,417 & 2,428 \\
\hline Inhaling & 7.9814 & 39.9072 & 0.00583 & 0.00117 & 2,431 & 2,431 \\
\hline \hline
\end{tabular}

The calculated benzene concentration profiles at 25 and $17 \mathrm{ft}$ fill heights are shown in Figure 8 and Figure 9, respectively. These profiles were obtained by alternating the solutions for the exhaling_1 and inhaling modes each with a 12-hour period. For example, the value of $y_{B Z N}$ obtained at the end of an exhaling mode was used as the initial value for the next 12-hour inhaling solution and vice versa. An illustration of this discrete solution approach will be given later in the report.

The final equilibrium concentration of benzene is calculated as the average of those for the exhaling and inhaling modes as $t \ddagger \infty$. For example, the equilibrium benzene concentration at 25 fill height is calculated as:

$$
\begin{aligned}
y_{B Z N}^{e q} & =\frac{y_{B Z N, E X H}(\infty)+y_{B Z N, I N H}(\infty)}{2} \\
& =\frac{Q F R C_{B Z N, E X H 1}+Q F R C_{B Z N, I N H}}{2} \\
& =\frac{0.00580+0.00583}{2} \\
& \approx 0.0058
\end{aligned}
$$

Equation 33

which means that atmospheric breathing would prevent the cell vapor from ever reaching the LFL. Furthermore, it is estimated to take 1,758 hours or 73 days to reach the $25 \%$ of the LFL or $y_{B Z N}=$ 0.003 at the $25 \mathrm{ft}$ fill height and the baseline benzene generation rate of $3.4 \mathrm{~g} / \mathrm{hr}$. As a comparison, it was estimated earlier that in the absence of atmospheric breathing it would take 1,252 hours or 52 days to reach $25 \%$ of the LFL. Therefore, it can be concluded that under the assumptions made in this work atmospheric breathing effectively increases the time to reach $25 \%$ of the LFL by $\sim 40 \%$ over the non-breathing case. 
WSRC-TR-2005-00071

Revision 1

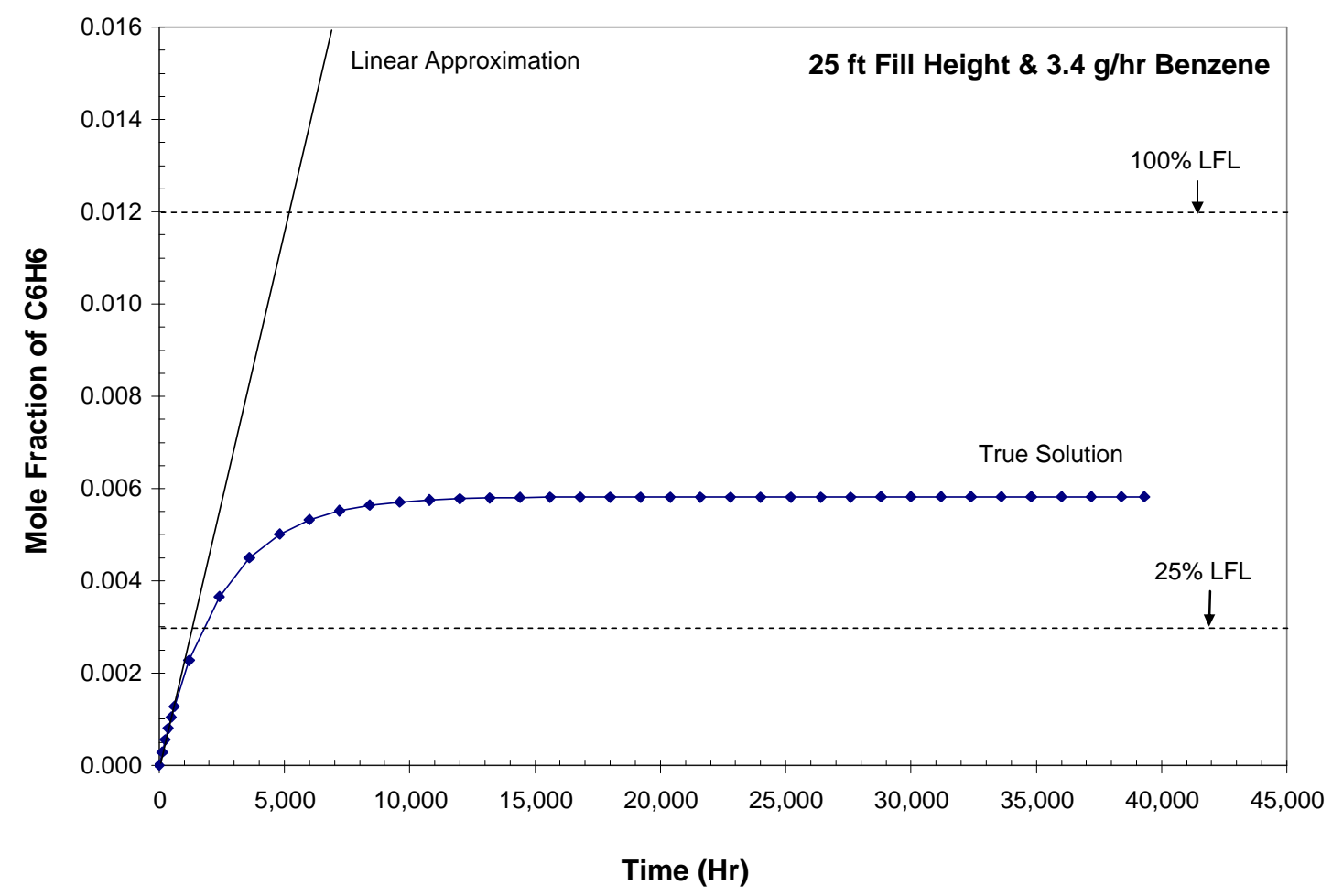

Figure 8. Benzene Concentration Profile in Cell Vapor Space at $25 \mathrm{ft}$ Fill Height.

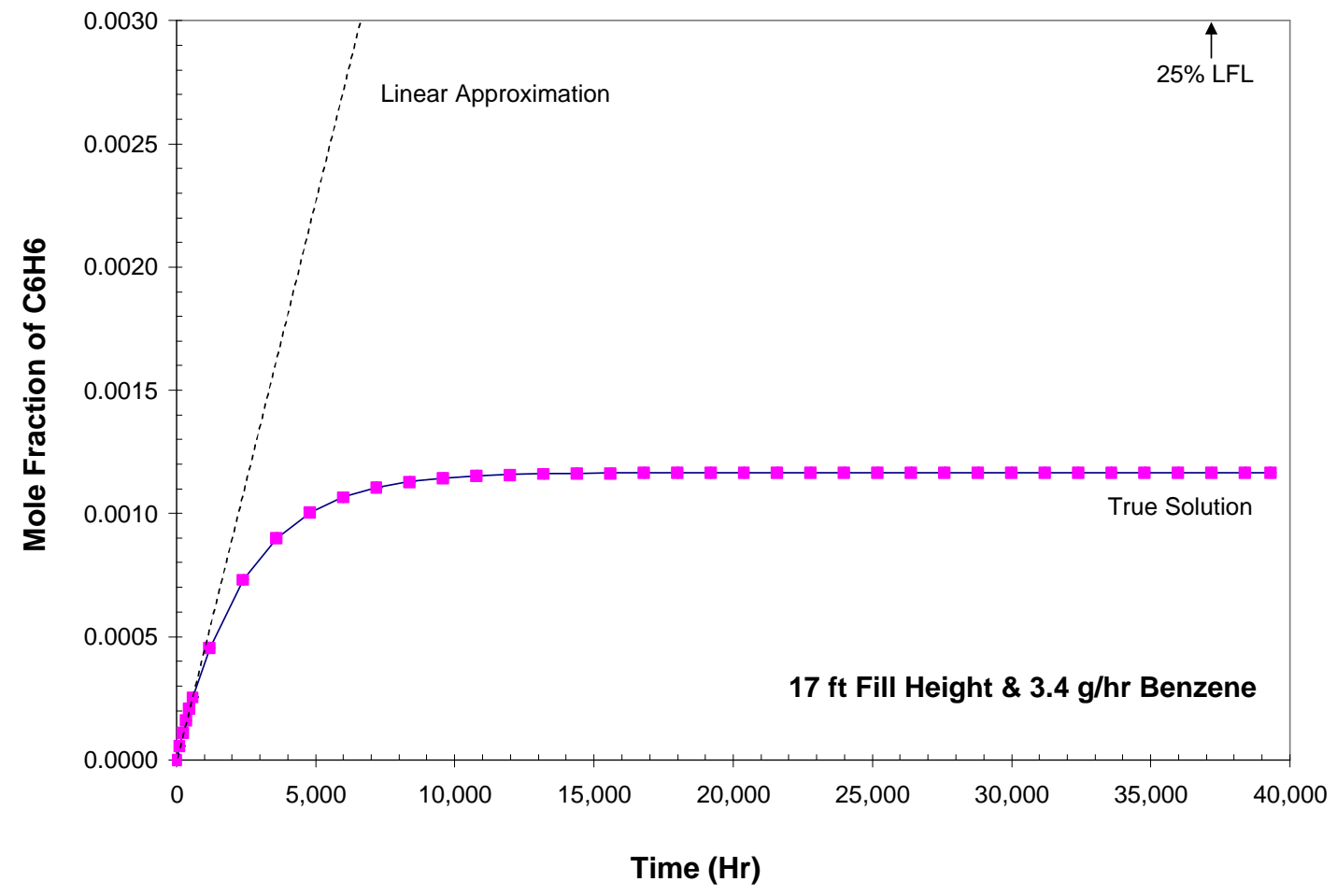

Figure 9. Benzene Concentration Profile in Cell Vapor Space at $17 \mathrm{ft}$ Fill Height. 
When the fill height was lowered to $17 \mathrm{ft}$, Figure 9 shows that the final equilibrium benzene concentration is reduced to $y_{B Z N}=0.0012$, i.e., by the same factor of $\sim 5$ over that at $25 \mathrm{ft}$ fill height. Therefore, it can be concluded that under the assumptions made in this work the potential for flammability in the cell vapor space is highly unlikely at the $17 \mathrm{ft}$ fill height and the baseline benzene generation rate of $3.4 \mathrm{~g} / \mathrm{hr}$.

The overall first-order time constant for the $25 \mathrm{ft}$ fill height is also calculated as the average of those for the exhaling and inhaling modes:

$$
\begin{aligned}
\tau & =\frac{\tau_{E X H}+\tau_{I N H}}{2} \\
& =\frac{2,417+2,431}{2} \\
& =2,424 \mathrm{hr}
\end{aligned}
$$

At the $2,424^{\text {th }}$ hour, the calculated concentration of benzene is:

$$
\begin{aligned}
y_{B Z N} & =0.003676 \\
& =63.2 \% \text { of } y_{B Z N}(\infty)
\end{aligned}
$$

which was expected for this first-order system.

It can be seen from Eq. (33) that the final equilibrium concentration of benzene at $\mathrm{t} \ddagger \infty$ depends on the value of $Q F R C_{B Z N}$ but not on the initial value, $y_{B Z N}(0)$. It is, however, important to note that the initial benzene concentration strongly impacts the time to LFL and that it was assumed in this work that there is no benzene in the vapor space initially after the grout is filled to any height (Assumption \#3). Since this is not a realistic assumption, the results presented here should be treated cautiously until suitable initial values are added to the solution algorithms. Nevertheless, the positive impact of atmospheric breathing has been clearly shown by the results, as summarized in Table 5 .

Table 5. Impact of Atmospheric Breathing at $3.4 \mathrm{~g} / \mathrm{hr}$ Benzene Generation Rate.

\begin{tabular}{||c|c|c|c|c||}
\hline \hline Fill Height (ft) & \multicolumn{2}{|c|}{25} & \multicolumn{2}{c||}{17} \\
\hline Mode of Breathing & $\begin{array}{c}\text { Atmospheric } \\
\text { Breathing }\end{array}$ & $\begin{array}{c}\text { No } \\
\text { Atmospheric } \\
\text { Breathing }\end{array}$ & $\begin{array}{c}\text { Atmospheric } \\
\text { Breathing }\end{array}$ & $\begin{array}{c}\text { No } \\
\text { Atmospheric } \\
\text { Breathing }\end{array}$ \\
\hline Equilibrium $y_{B Z N}$ & 0.0058 & 1.0000 & 0.0012 & 1.0000 \\
\hline Time to LFL (day) & $\bullet$ & 210 & $\bullet$ & 1,048 \\
\hline Time to 25\% of LFL (day) & 73 & 52 & $\bullet$ & 261 \\
\hline \hline
\end{tabular}

The following algorithm for estimating the equilibrium benzene concentration for the (Exhaling_ $1+$ Inhaling) breathing pair can be obtained from Eq. (33) by substituting appropriate $Q F R C_{B Z N}$ 's:

$$
y_{B Z N}^{e q}=\frac{Q_{B Z N}\left(Q_{B Z N}+2 Q_{A B}\right)}{2 Q_{A B}\left(Q_{B Z N}+Q_{A B}\right)}
$$




\subsection{Atmospheric Breathing at 10X Baseline Benzene Generation}

In the $3^{\text {rd }}$ case, the benzene generation rate was set at 10 times the baseline rate or $34 \mathrm{~g} / \mathrm{hr}$ and the corresponding volumetric rate $Q_{B Z N}$ is calculated to be $0.46552 \mathrm{ft}^{3} / \mathrm{hr}$. Since $Q_{B Z N}<Q_{A B}$ at both fill heights, the relevant breathing pair is still (Exhaling_l + Inhaling). The calculated values of $Q F R C_{B Z N}$ and $\tau$ are tabulated in Table 6 :

Table 6. Values of Solution Parameters at $34 \mathrm{~g} / \mathrm{hr}$ Benzene Generation Rate.

\begin{tabular}{||c|c|c|c|c|c|c||}
\hline \multirow{2}{*}{ Breathing Mode } & \multicolumn{2}{|c|}{$Q_{A B}\left(f^{3} / h r\right)$} & \multicolumn{2}{c|}{$Q F R C_{B Z N}$} & \multicolumn{2}{c|}{$\tau(h r)$} \\
\cline { 2 - 8 } & $H=25 f t$ & $H=17 f t$ & $H=25 f t$ & $H=17 f t$ & $H=25 f t$ & $H=17 f t$ \\
\hline Exhaling_1 & 7.9814 & 39.9072 & 0.05511 & 0.01153 & 2,297 & 2,403 \\
\hline Inhaling & 7.9814 & 39.9072 & 0.05833 & 0.01167 & 2,431 & 2,431 \\
\hline
\end{tabular}

The calculated benzene concentration profiles at 25 and $17 \mathrm{ft}$ fill heights are shown in Figure 10 and Figure 11, respectively, for the benzene generation rate of $34 \mathrm{~g} / \mathrm{hr}$. It is projected to take 562 hours or 23 days to reach the LFL at $25 \mathrm{ft}$ fill height, and the final equilibrium concentration of $y_{B Z N}=0.0567$ or 4.7 times the LFL is $\sim 10$ times that at the baseline benzene generation rate. As a comparison, the projected equilibrium benzene mole fraction at $17 \mathrm{ft}$ fill height is 0.0116 , still a tad below the LFL due to 5 times higher atmospheric breathing rate. It is shown in Table 7 that the positive impact of atmospheric breathing as evidenced by the increased time to LFL for the baseline case (Table 5) over the non-breathing case has diminished significantly at $25 \mathrm{ft}$ fill height when the benzene generation rate is increased by a factor of 10 to $34 \mathrm{~g} / \mathrm{hr}$.

Table 7. Impact of Atmospheric Breathing at $34 \mathrm{~g} / \mathrm{hr}$ Benzene Generation Rate.

\begin{tabular}{||c|c|c|c|c||}
\hline \hline Fill Height (ft) & \multicolumn{2}{|c|}{25} & \multicolumn{2}{c||}{17} \\
\hline Mode of Breathing & $\begin{array}{c}\text { Atmospheric } \\
\text { Breathing }\end{array}$ & $\begin{array}{c}\text { No } \\
\text { Atmospheric } \\
\text { Breathing }\end{array}$ & $\begin{array}{c}\text { Atmospheric } \\
\text { Breathing }\end{array}$ & $\begin{array}{c}\text { No } \\
\text { Atmospheric } \\
\text { Breathing }\end{array}$ \\
\hline Equilibrium $y_{B Z N}$ & 0.0567 & 1.0000 & 0.0116 & 1.0000 \\
\hline Time to LFL (day) & 23 & 21 & $\bullet$ & 105 \\
\hline Time to 25\% of LFL (day) & 5.3 & 5.2 & 30 & 26 \\
\hline \hline
\end{tabular}


WSRC-TR-2005-00071

Revision 1

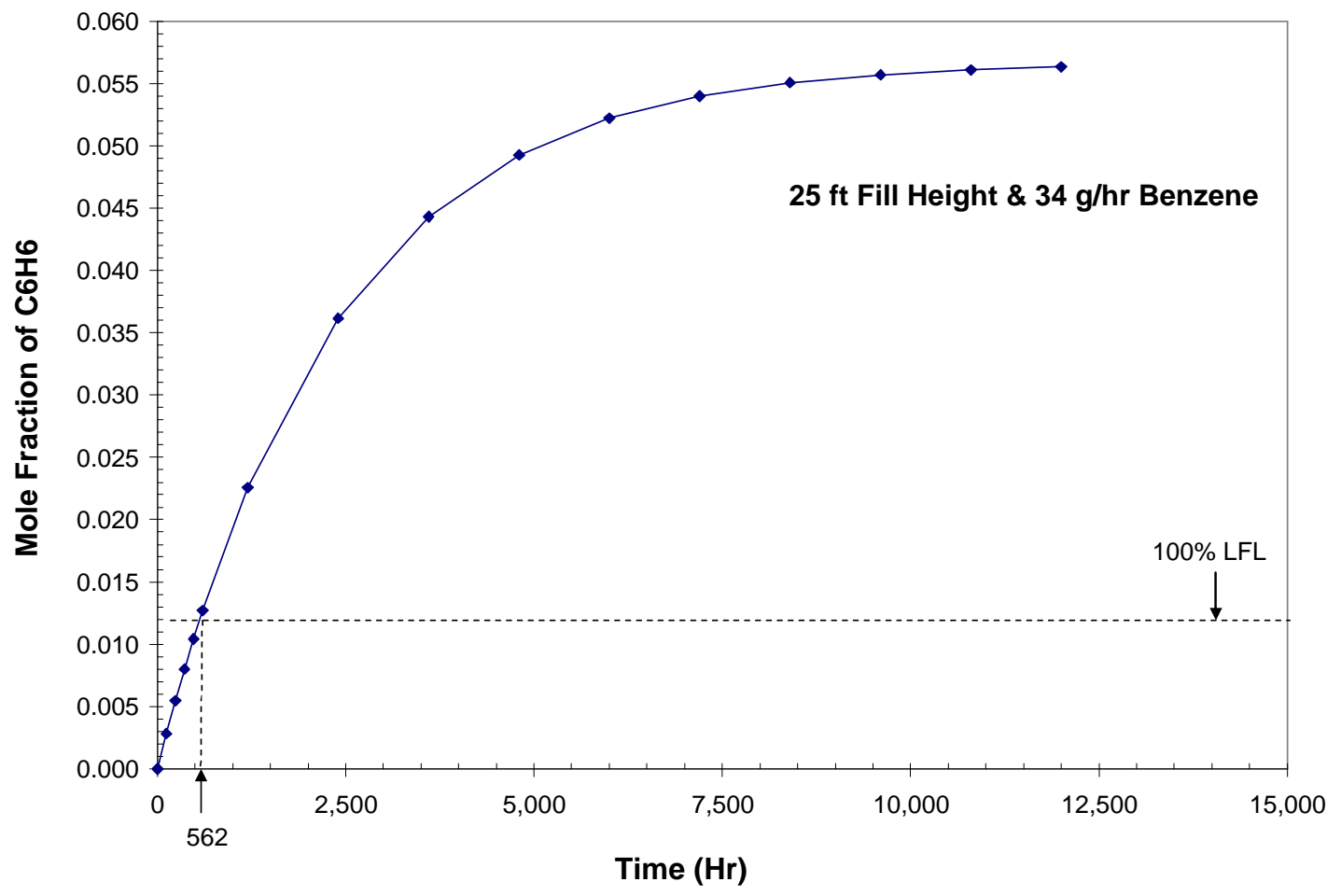

Figure 10. Benzene Concentration Profile at $34 \mathrm{~g} / \mathrm{hr}$ Benzene Rate \& $25 \mathrm{ft}$ Fill Height.

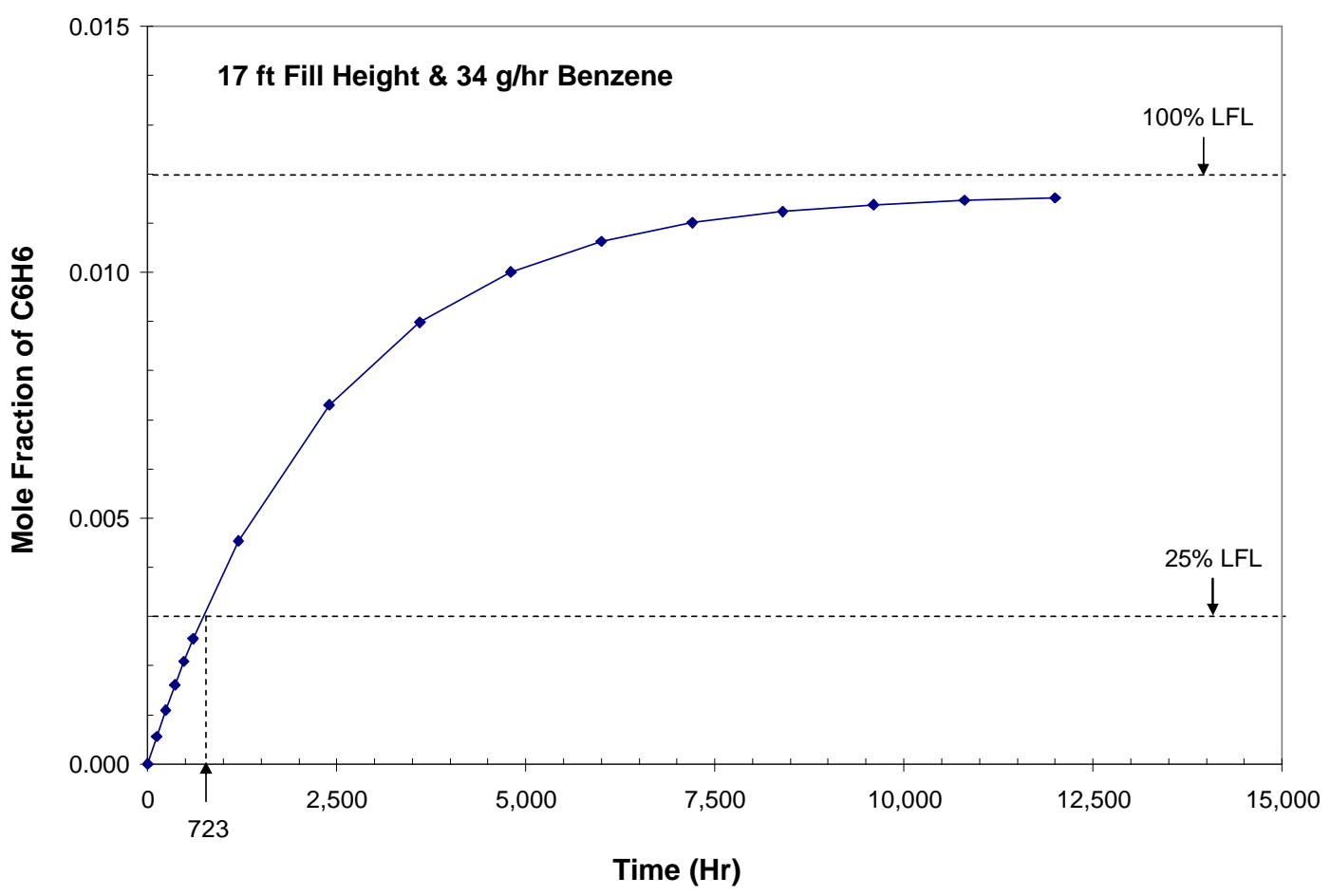

Figure 11. Benzene Concentration Profile at $34 \mathrm{~g} / \mathrm{hr}$ Benzene Rate \& $17 \mathrm{ft}$ Fill Height. 


\subsection{Atmospheric Breathing at 100X Baseline Benzene Generation}

In the $4^{\text {th }}$ case, the benzene generation rate was set at 100 times the baseline rate or $340 \mathrm{~g} / \mathrm{hr}$ and the corresponding volumetric rate $Q_{B Z N}$ is calculated to be $4.6552 \mathrm{ft}^{3} / \mathrm{hr}$. Since $Q_{B Z N}<Q_{A B}$ at both fill heights, the relevant breathing pair is still (Exhaling_l + Inhaling). The calculated values of $Q F R C_{B Z N}$ and $\tau$ are tabulated in Table 8:

Table 8. Values of Solution Parameters at $340 \mathrm{~g} / \mathrm{hr}$ Benzene Generation Rate.

\begin{tabular}{||c|c|c|c|c|c|c||}
\hline \multirow{2}{*}{ Breathing Mode } & \multicolumn{2}{|c|}{$Q_{A B}\left(f t^{3} / h r\right)$} & \multicolumn{2}{c|}{$Q F R C_{B Z N}$} & \multicolumn{2}{c||}{$\tau(h r)$} \\
\cline { 2 - 7 } & $H=25 f t$ & $H=17 f t$ & $H=25 f t$ & $H=17 f t$ & $H=25 f t$ & $H=17 f t$ \\
\hline Exhaling_1 & 7.9814 & 39.9072 & 0.3684 & 0.1045 & 1,536 & 2,177 \\
\hline Inhaling & 7.9814 & 39.9072 & 0.5833 & 0.1167 & 2,431 & 2,431 \\
\hline \hline
\end{tabular}

The calculated benzene concentration profiles at 25 and $17 \mathrm{ft}$ fill heights are shown in Figure 12 and Figure 13, respectively, for the benzene generation rate of $340 \mathrm{~g} / \mathrm{hr}$. At $25 \mathrm{ft}$ fill height, it is projected to take 51 hours to reach the LFL on its way to the final equilibrium concentration of $y_{B Z N}=0.4758$. As a comparison, it is projected to take 265 hours to reach the LFL at $17 \mathrm{ft}$ fill height and the projected equilibrium benzene mole fraction is 0.1106. It is also shown in Table 9 that the positive impact of atmospheric breathing as evidenced by the increased time to LFL for the baseline case (Table 5) over the non-breathing case has pretty much vanished for both fill heights when the benzene generation rate is increased by a factor of 100 to $340 \mathrm{~g} / \mathrm{hr}$.

Table 9. Impact of Atmospheric Breathing at $340 \mathrm{~g} / \mathrm{hr}$ Benzene Generation Rate.

\begin{tabular}{||c|c|c|c|c||}
\hline \hline Fill Height (ft) & \multicolumn{2}{|c|}{25} & \multicolumn{2}{c||}{17} \\
\hline Mode of Breathing & $\begin{array}{c}\text { Atmospheric } \\
\text { Breathing }\end{array}$ & $\begin{array}{c}\text { No } \\
\text { Atmospheric } \\
\text { Breathing }\end{array}$ & $\begin{array}{c}\text { Atmospheric } \\
\text { Breathing }\end{array}$ & $\begin{array}{c}\text { No } \\
\text { Atmospheric } \\
\text { Breathing }\end{array}$ \\
\hline Equilibrium $y_{B Z N}$ & 0.4758 & 1.0000 & 0.1106 & 1.0000 \\
\hline Time to LFL (hr) & 51 & 50 & 265 & 252 \\
\hline Time to 25\% of LFL (hr) & 13 & 13 & 63 & 63 \\
\hline \hline
\end{tabular}


WSRC-TR-2005-00071

Revision 1

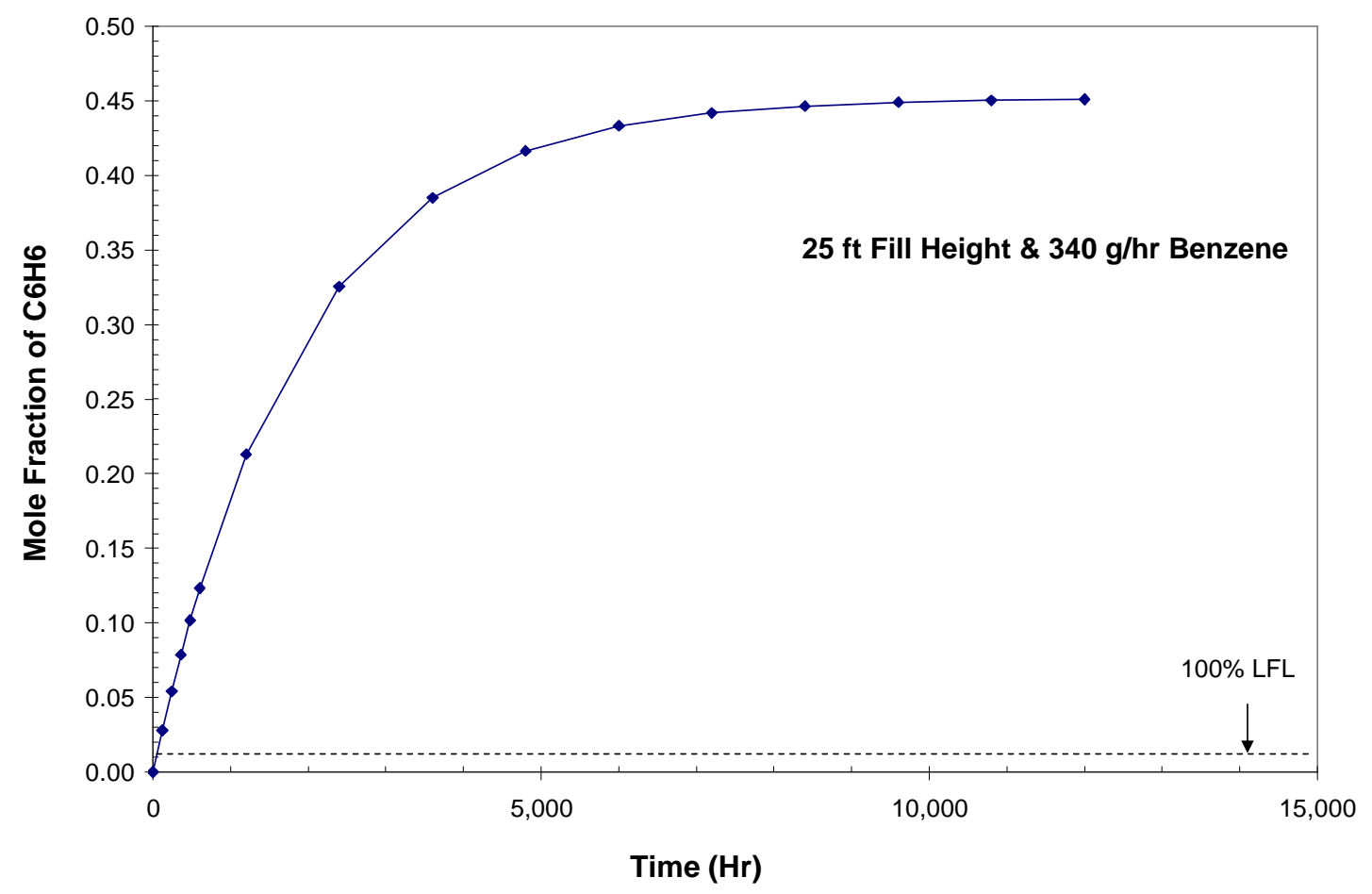

Figure 12. Benzene Concentration Profile at $340 \mathrm{~g} / \mathrm{hr}$ Benzene Rate \& $25 \mathrm{ft}$ Fill Height.

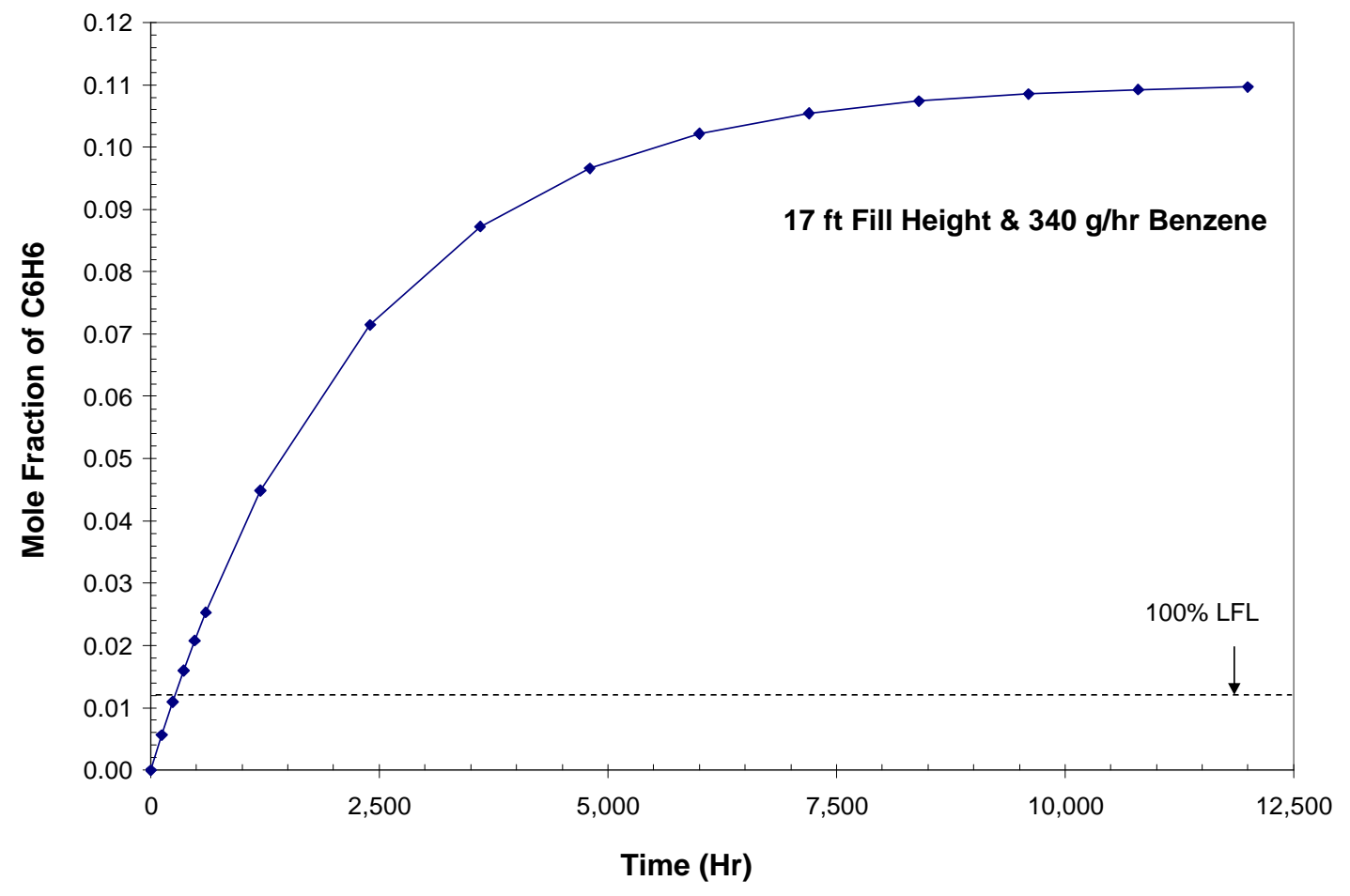

Figure 13. Benzene Concentration Profile at $340 \mathrm{~g} / \mathrm{hr}$ Benzene Rate \& $17 \mathrm{ft}$ Fill Height. 


\subsection{Atmospheric Breathing at 1000X Baseline Benzene Generation}

In the last case considered, the benzene generation rate was set at 1,000 times the baseline rate or $3,400 \mathrm{~g} / \mathrm{hr}$, and the corresponding volumetric rate $Q_{B Z N}$ is calculated to be $46.552 \mathrm{ft}^{3} / \mathrm{hr}$. At both fill heights, the benzene generation rate $Q_{B Z N}$ is now higher than the atmospheric breathing rate $Q_{A B}$ and the relevant breathing pair is (Exhaling_1 + Exhaling_2). The calculated values of $Q F R C_{B Z N}$ and $\tau$ are tabulated in Table 10:

Table 10. Values of Solution Parameters at 3,400 g/hr Benzene Generation Rate.

\begin{tabular}{||c|c|c|c|c|c|c||}
\hline \multirow{2}{*}{ Breathing Mode } & \multicolumn{2}{|c|}{$Q_{A B}\left(f t^{3} / h r\right)$} & \multicolumn{2}{c|}{$Q F R C_{B Z N}$} & \multicolumn{2}{c||}{$\tau(h r)$} \\
\cline { 2 - 7 } & $H=25 f t$ & $H=17 f t$ & $H=25 f t$ & $H=17 f t$ & $H=25 f t$ & $H=17 f t$ \\
\hline Exhaling_1 & 7.9814 & 39.9072 & 0.8536 & 0.5384 & 356 & 1,122 \\
\hline Exhaling_2 & 7.9814 & 39.9072 & 1.2069 & 7.0022 & 503 & 14,593 \\
\hline \hline
\end{tabular}

The calculated benzene concentration profiles at 25 and $17 \mathrm{ft}$ fill heights are shown in Figure 14 and Figure 15, respectively, for the benzene generation rate of $3,400 \mathrm{~g} / \mathrm{hr}$. At $25 \mathrm{ft}$ fill height, it is projected to take only 5 hours to reach the LFL and fill the entire vapor space with pure benzene after $\sim 2,500$ hours. As a comparison, it is projected to take 25 hours to reach the LFL at $17 \mathrm{ft}$ fill height and also eventually fill the entire vapor space with pure benzene. It is shown in Table 11 that at either fill height the atmospheric breathing no longer has any positive impact on either the time to LFL or the final equilibrium concentration of benzene, compared to the non-breathing case.

Table 11. Impact of Atmospheric Breathing at 3,400 $\mathrm{g} / \mathrm{hr}$ Benzene Generation Rate.

\begin{tabular}{||c|c|c|c|c||}
\hline Fill Height (ft) & \multicolumn{2}{|c|}{25} & \multicolumn{2}{c||}{17} \\
\hline Mode of Breathing & $\begin{array}{c}\text { Atmospheric } \\
\text { Breathing }\end{array}$ & $\begin{array}{c}\text { No } \\
\text { Atmospheric } \\
\text { Breathing }\end{array}$ & $\begin{array}{c}\text { Atmospheric } \\
\text { Breathing }\end{array}$ & $\begin{array}{c}\text { No } \\
\text { Atmospheric } \\
\text { Breathing }\end{array}$ \\
\hline Equilibrium $y_{B Z N}$ & 1.0000 & 1.0000 & 1.0000 & 1.0000 \\
\hline Time to LFL (hr) & 5.0 & 5.0 & 25 & 25 \\
\hline Time to 25\% of LFL (hr) & 1.3 & 1.3 & 6.3 & 6.3 \\
\hline
\end{tabular}

The following algorithm for estimating the equilibrium benzene concentration for the (Exhaling_l + Exhaling_2) breathing pair can be obtained from Eq. (33) by substituting appropriate $Q F R C_{B Z N}$ 's:

$$
y_{B Z N}^{e q}=\frac{Q_{B Z N}{ }^{2}}{Q_{B Z N}{ }^{2}-Q_{A B}{ }^{2}}
$$


WSRC-TR-2005-00071

Revision 1

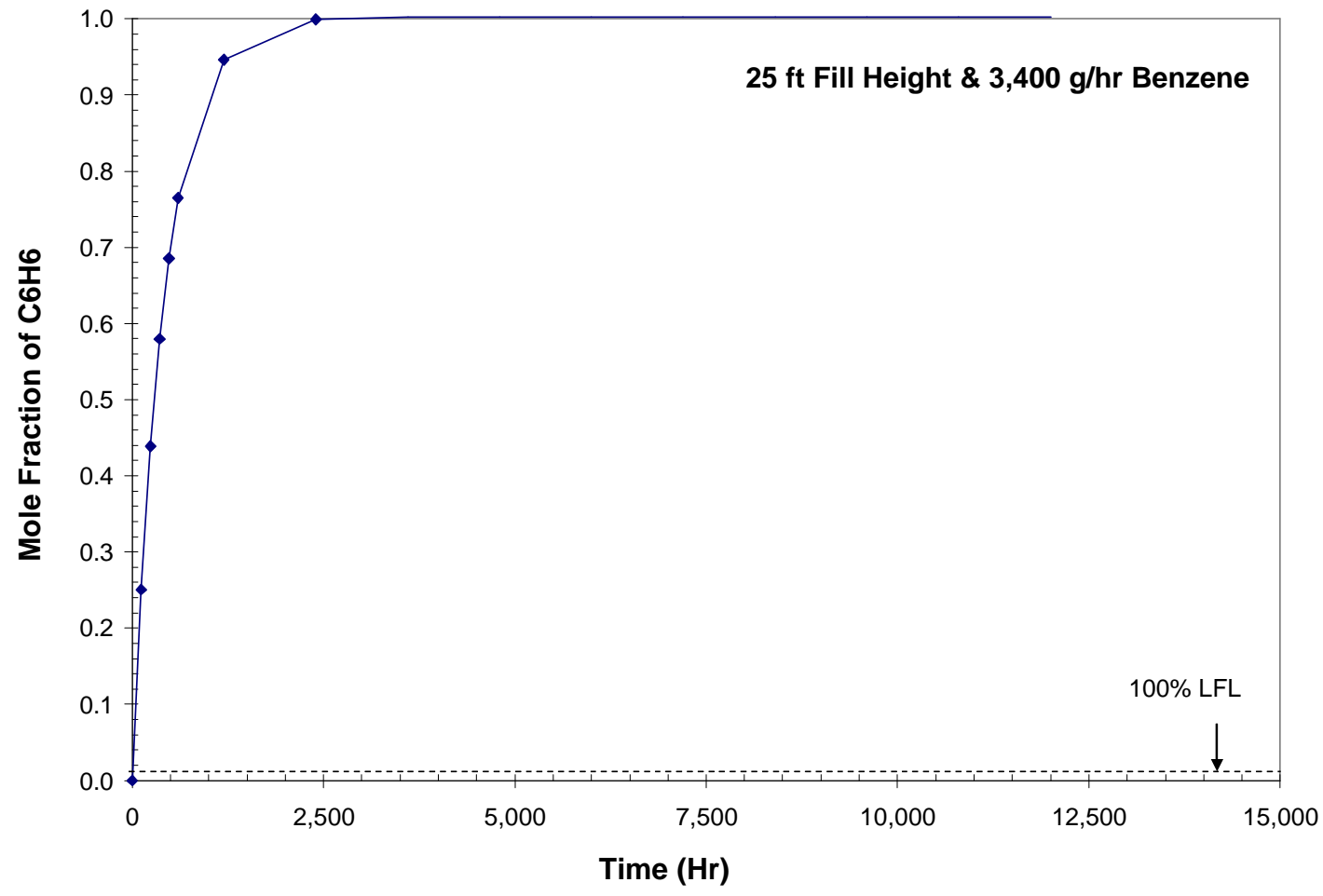

Figure 14. Benzene Concentration Profile at 3,400 g/hr Benzene Rate \& $25 \mathrm{ft}$ Fill Height.

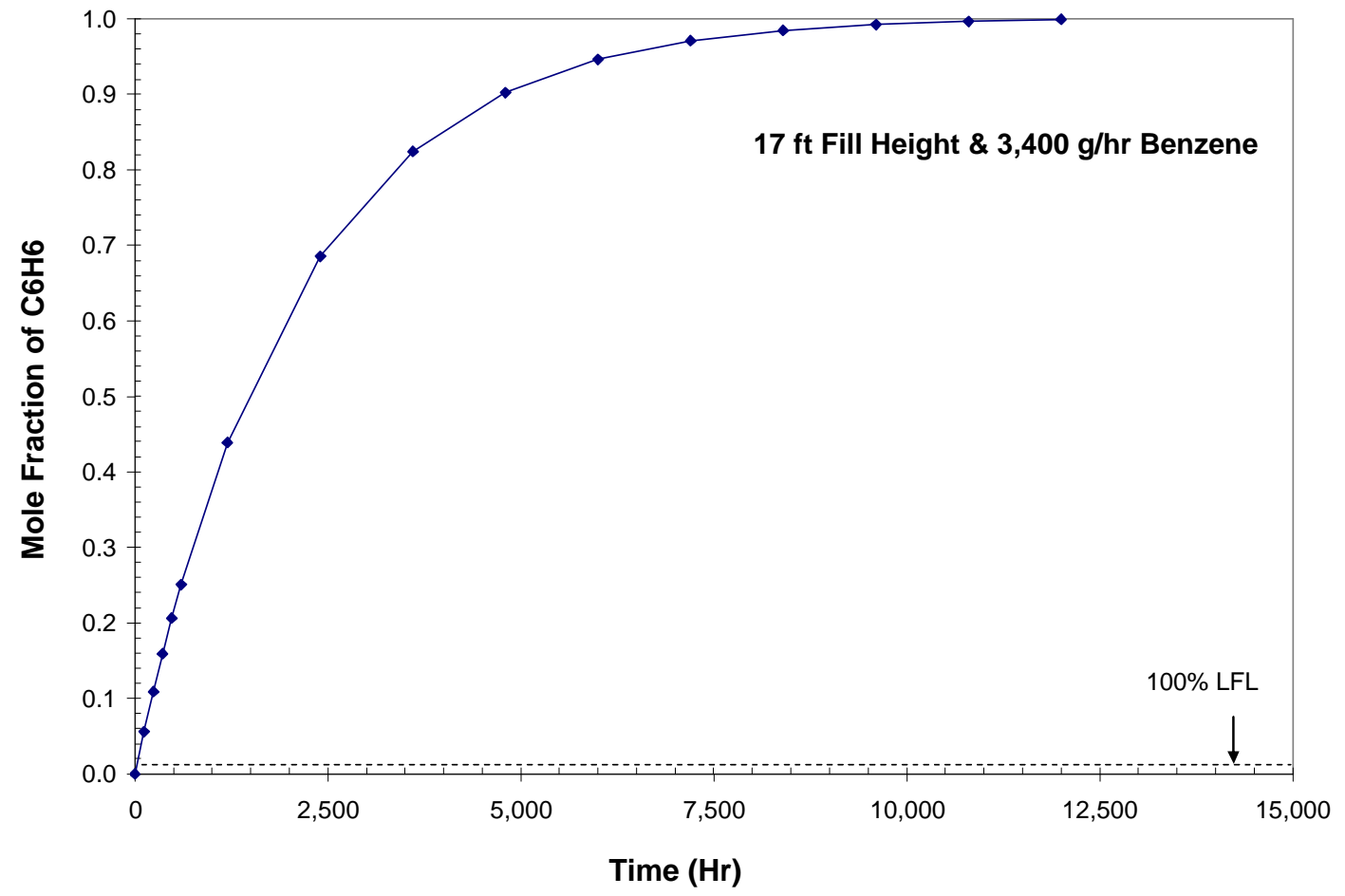

Figure 15. Benzene Concentration Profile at 3,400 g/hr Benzene Rate \& $17 \mathrm{ft}$ Fill Height. 
If we were to re-plot the benzene concentration profiles shown earlier on a finer time-scale, we would find that they are not smooth. Instead, they would look zigzagged especially at larger times, as shown by the "overall" breathing curve in Figure 16. The reason for zigzagging is that these profiles were obtained by alternating the average solutions of the Exhaling_1 and Exhaling_2 at a 12-hour interval; the value of $y_{B Z N}$ at the end of the Exhaling_1 mode was used as the initial value for the next 12-hour Exhaling_2 solution or vice versa. The two dotted curves in Figure 16 represent the discrete solutions to the Exhaling_1 and Exhaling_2 equations obtained using the cumulative time scale instead of the fresh 12-hour duration for each breathing cycle. The two curves are dotted or discontinuous, since each 12-hour breathing cycle occurs only once in a 24-hour period. And the zigzagging of the "overall" breathing curve results when the two dotted curves are averaged.

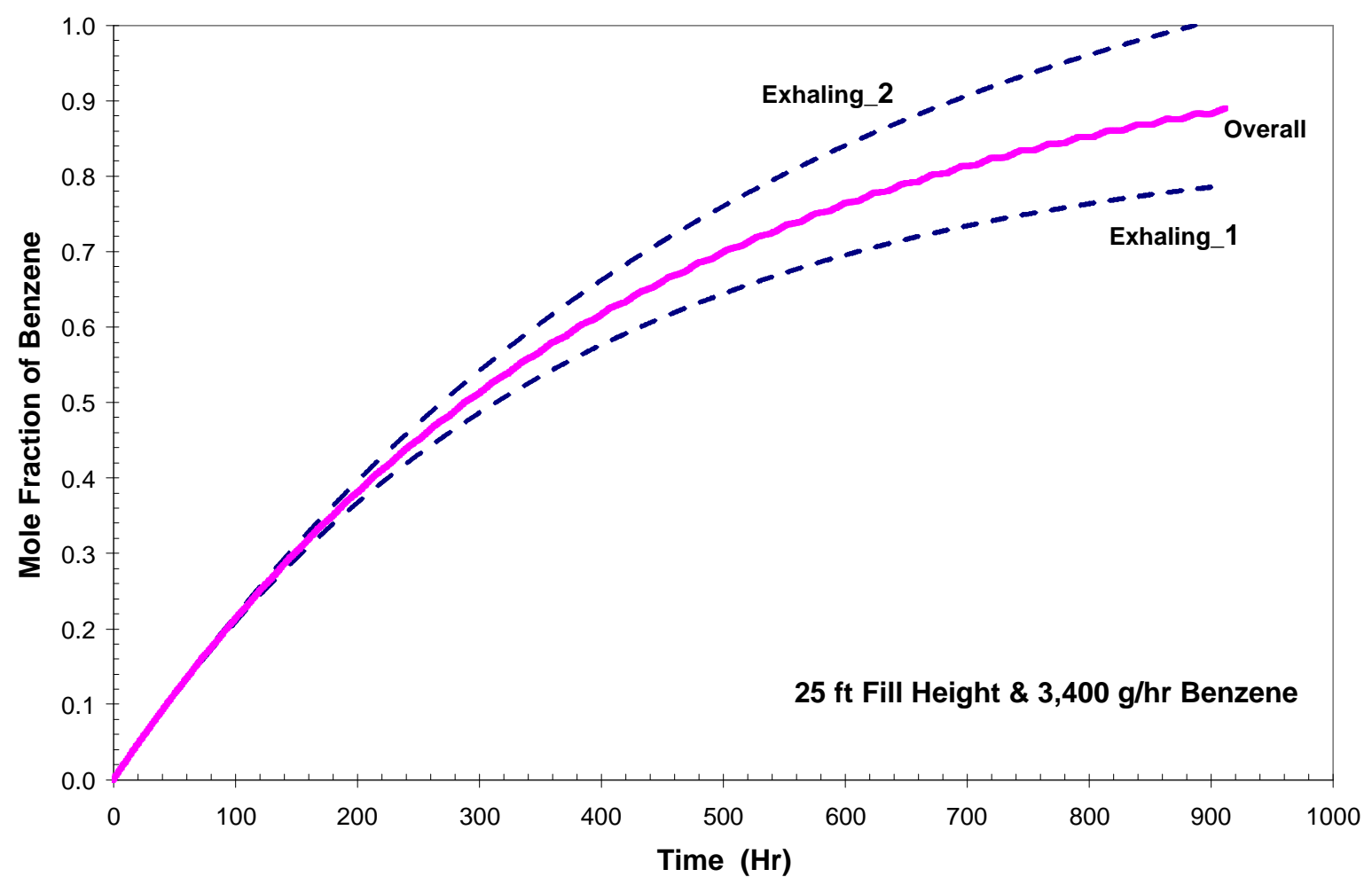

Figure 16. Components of Benzene Concentration Profile at 3,400 g/hr Benzene Rate. 
WSRC-TR-2005-00071

Revision 1

This page intentionally left blank. 


\subsection{CONCLUSIONS}

Under the assumptions made in this study, it can be concluded that:

- At $3.4 \mathrm{~g} / \mathrm{hr}$ benzene generation rate, passive breathing induced by the diurnal oscillations of barometric pressure is sufficient enough to limit the maximum benzene concentration below $50 \%$ of the LFL in the cell vapor space at any fill height without active ventilation.

- At $34 \mathrm{~g} / \mathrm{hr}$ benzene generation rate, it is estimated to take 23 and 5 days to reach $100 \%$ and $25 \%$ of the LFL, respectively, at $25 \mathrm{ft}$ fill height. At $17 \mathrm{ft}$ fill height, it is estimated to take 30 days to reach $25 \%$ of the LFL with the maximum benzene concentration just below the LFL.

- At $34 \mathrm{~g} / \mathrm{hr}$ benzene generation rate, the advantage of passive breathing over the non-breathing case becomes only marginal at $25 \mathrm{ft}$ fill height.

- At benzene generation rates higher than $340 \mathrm{~g} / \mathrm{hr}$, passive breathing has no positive impact on the time to LFL at both 17 and $25 \mathrm{ft}$ fill heights.

- These flammability assessments should be regarded as conservative based on the finding that Eq. (10) would most likely under predict passive breathing rate by a significant margin.

The following algorithms were developed to be used for scoping purposes: ${ }^{1}$

- Cell vapor space volume $\left(f t^{3}\right)$ :

- $\quad$ Atmospheric breathing rate $\left(f t^{3} / h r\right)$ :

$$
V=9,702.25(27-H)
$$

$$
Q_{A B}=1,617.042(27-H) \frac{\Delta P}{P_{o}}
$$

- Equilibrium benzene concentration (mole fraction):

- Exhaling_1 + Inhaling:

$$
y_{B Z N}^{e q}=\frac{Q_{B Z N}\left(Q_{B Z N}+2 Q_{A B}\right)}{2 Q_{A B}\left(Q_{B Z N}+Q_{A B}\right)}
$$

- Exhaling_1 + Exhaling_2:

$$
y_{B Z N}^{e q}=\frac{Q_{B Z N}{ }^{2}}{{Q_{B Z N}{ }^{2}-Q_{A B}{ }^{2}}^{2}}
$$

The following algorithms were developed for a quick estimation of equilibrium benzene mole fraction at a given benzene generation rate by curve-fitting calculated data, as shown in Figures 17 and 18:

- At $25 \mathrm{ft}$ fill height:

$$
\begin{aligned}
& \frac{1}{y_{B Z N}}=0.37627+\frac{586.581}{\dot{m_{B Z N}}} \\
& \frac{1}{y_{B Z N}}=0.46973+\frac{2,915.163}{\dot{m_{B Z N}}}
\end{aligned}
$$




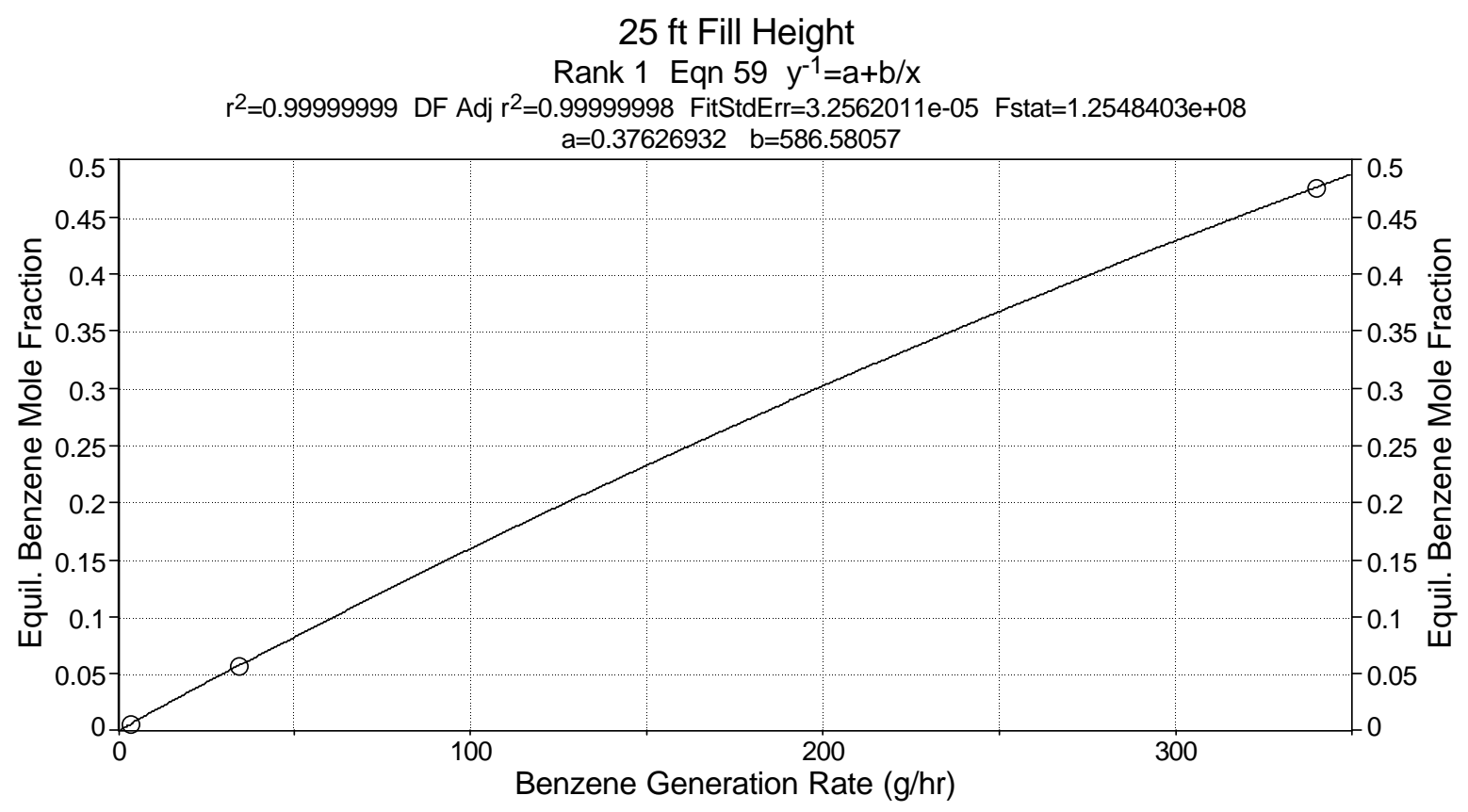

Figure 17. Equilibrium Benzene Concentration Profile at 25 Ft Fill Height.

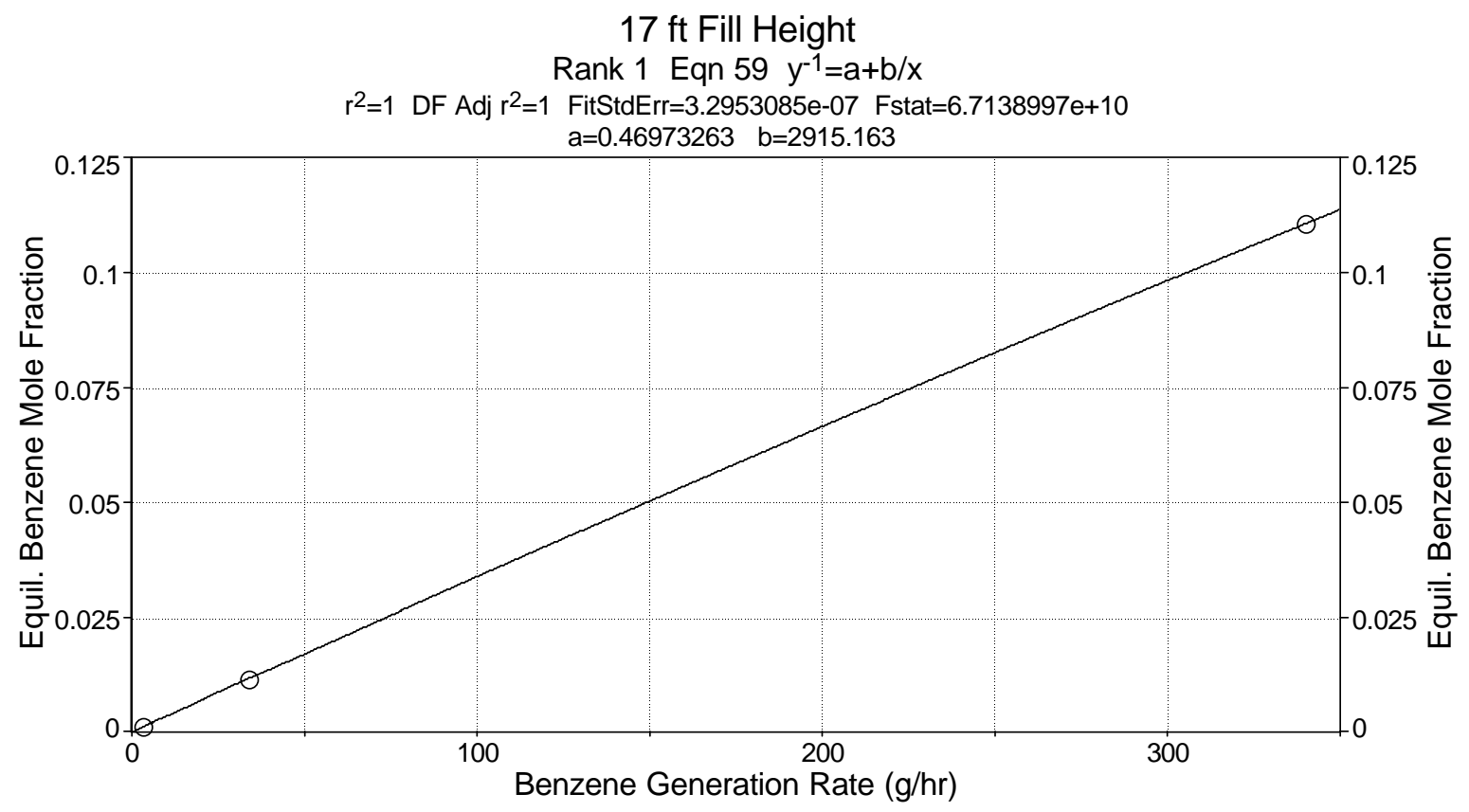

Figure 18. Equilibrium Benzene Concentration Profile at 17 Ft Fill Height. 


\subsection{RECOMMENDATIONS/PATH FORWARD}

As stated in the Technical Task Request (TTR), ${ }^{1}$ the purpose of this work was to develop the algorithms that can be used for scoping purposes to quantify the impact of atmospheric breathing on the benzene concentration that is expected to build up in the cell vapor space during the grout curing process. In doing so, it was necessary to make several simplifying assumptions, some of which were not necessarily bounding.

Specifically, it is recommended that

- The assumed "zero" initial benzene concentration in the cell (Assumption \#3) be replaced with some bounding value based on recent experimental findings.

- The assumed perfect-mixing in the vapor space (Assumption \#5) be supplemented by looking into the effects of gas layering or partitioning.

- A preliminary CFD study conducted earlier be extended to examine how convective flows are established in the cell vapor space under more realistic operating and design conditions, i.e., taking into account transient heat emission from the grout matrix, both diurnal and seasonal variations in the solar heating flux, etc.

- The degree of under prediction of passive breathing by Eq. (10) be quantified by taking both chimney and wind effects into consideration. 
WSRC-TR-2005-00071

Revision 1

This page intentionally left blank. 


\subsection{REFERENCES}

1. Technical Task Request, SSF-TTR-2004-0007, Westinghouse Savannah River Co., Aiken, South Carolina, November 18, 2004.

2. Auer, L. H., Rosenberg, N. D., Birdsell, K. H., and Whitney, E. M., "The effects of barometric pumping on contaminant transport," J. Contam. Hydrol., 24, 145-166 (1996).

3. Nilson, R. H., Peterson, E. W., Lie, K. H., Burkhard, N. R., and Hears, J. R., "Atmospheric Pumping: A Mechanism Causing Vertical Transport of Contaminated Gases Through Fractured Permeable Media,” J. Geophys. Res., 96, No. B13, pp 21933-21948 (1991).

4. Huckaby, J. L., Evans, J. C., Olsen, K. B., Remund, K. M., and Sklarew, D. S., "Measurements of Waste Tank Passive Ventilation Rates Using Tracer Gases," PNNL-11683, Pacific Northwest National Laboratory, Richland, Washington, 1997.

5. Huckaby, J. L., Evans, J. C., Sklarew, D. S., and Mitroshkov, A. V., "Waste Tank Ventilation Rates Measured with a Tracer Gas Method," PNNL-11925, Pacific Northwest National Laboratory, Richland, Washington, 1998.

6. Hanlon, B. M., "Waste Tank Summary Report for Month Ending January 31, 2005," HNF-EP-0182, Rev. 202, CH2M Hill Hanford Group, Inc., Richland, Washington, 2005.

7. Barker, S. A., "Determination of Hanford Waste Tank Volumes," RPP-13019, Rev. 0, CH2M Hill Hanford Group, Inc., Richland, Washington, 2003.

8. 1997 Hourly Barometric Pressure Data for Hanford Site (ASCII file) obtained from K. W. Burk of Pacific Northwest National Laboratory, Richland, Washington, February 2006.

9. 1998 Hourly Barometric Pressure Data for Hanford Site (ASCII file) obtained from K. W. Burk of Pacific Northwest National Laboratory, Richland, Washington, February 2006.

10. Lee, S. Y, "Computational Fluid Dynamics Model for Saltstone Vault 4 Vapor Space," WSRC-TR-2005-00288, Rev. 1, Westinghouse Savannah River Co., Aiken, South Carolina, August 2005.

11. Droppo, Jr., J. G., “Testing IH Instrumentation: Analysis of 1996-1998 Tank Ventilation Data in Terms of Characterizing a Transient Release," PNNL-14765, Pacific Northwest National Laboratory, Richland, Washington, 2004. 


\section{Distribution:}
J. E. Marra, 773-A
R. E. Edwards, 773-A
D. A. Crowley, 999-W
C. C. Herman, 999-W
T. B. Calloway, 999-W
N. E. Bibler, 773-A
C.M. Jantzen, 773-A
J. R. Harbour, 773-42A
C. A. Langton, 773-43A
G. C. Wicks, 773-A
J. C. Marra, 773-42A
A. D. Cozzi, 773-43A
F. G. Smith, 773-42A
J. R. Zamecnik, 999-W
A. S. Choi, 773-42A

M. S. Miller, 704-S

J. E. Occhipinti, 704-S

D. C. Sherburne, 704-S

W. B. Van-Pelt, 704-S

J. W. Ray, 704-S

J. F. Iaukea, 704-30S

R. M. Hoeppel, 704-27S

M. A. Rios-Armstrong, 704-27S

A. B. Sanders, 704-27S

T. E. Chandler, 704-Z 